Karen Batista de Morais

\title{
Purificação e caracterização da antitrombina do plasma da serpente Bothrops jararaca (Wied, 1824) (Ophidia: Viperidae, Crotalinae)
}

São Paulo 
Karen Batista de Morais

\section{Purificação e caracterização da antitrombina do plasma da serpente Bothrops jararaca (Wied, 1824) (Ophidia: Viperidae, Crotalinae)}

Dissertação apresentada ao Instituto de Biociências da Universidade de São Paulo, para a obtenção de Título de Mestre em Ciências, na Área de Fisiologia Geral.

Orientadora: Dra. Ida Sigueko Sano Martins

São Paulo 


\section{Morais, Karen Batista de}

Purificação e caracterização da antitrombina do plasma da serpente Bothrops jararaca (Wied 1824) (Ophidia: Viperidae, Crotalinae)

93 páginas

Dissertação (Mestrado) - Instituto de Biociências da Universidade de São Paulo. Departamento de Fisiologia.

1. Antitrombina 2. Bothrops jararaca 3. Hemostasia comparada I. Universidade de São Paulo. Instituto de Biociências. Departamento de Fisiologia.

\section{Comissão Julgadora:}

$\operatorname{Prof}(\mathrm{a}) . \operatorname{Dr}(\mathrm{a})$.

$\operatorname{Prof}(a) . \operatorname{Dr}(a)$.
$\operatorname{Prof}(\mathrm{a}) . \operatorname{Dr}(\mathrm{a})$.

$\operatorname{Prof}(\mathrm{a}) . \operatorname{Dr}(\mathrm{a})$.

Prof (a). Dr(a).

Orientador(a) 
Aos meus pais, Fábio e Déa, pelo incentivo, carinho e paciência.

Ao Guilherme, pelo amor, companheirismo e apoio. 


\section{Agradecimentos}

Ao Laboratório de Fisiopatologia do Instituto Butantan, por permitir a realização deste trabalho.

À Dra. Anita Mitico Tanaka Azevedo, pela orientação, ensinamentos e amizade.

À Dra. Ida Sigueko Sano Martins, pela colaboração e pela orientação oficial perante o Instituto de Biociências da Universidade de São Paulo.

Ao Dr. Marcelo Larami Santoro, pelas valiosas sugestões e pelo auxílio em alguns experimentos.

À Dra. Isaura Hirata, pelo seqüenciamento dos aminoácidos.

À Carolina Okamoto Vieira, pela ajuda constante.

Ao Laboratório de Farmacologia do Instituto Butantan, por permitir a sangria das serpentes B. jararaca.

A todos do Laboratório de Fisiopatologia, pelo companheirismo e incentivo.

À Coordenação de Aperfeiçoamento de Pessoal de Nível Superior (CAPES), pelo apoio financeiro. 


\section{Índice}

\section{INTRODUCÃO}

1.1. BOTHROPS JARARACA

1.2. HEMOSTASIA

1.3. INIBIDORES DE SERINOPROTESES (SERPINAS)

1.4. ANTITROMBINA

1.5. HEMOSTASIA COMPARADA

2. OBJETIVOS

28

3. MATERIAIS E MÉTODOS

3.1. MATERIAis

3.1.1. ANIMAIS

3.1.1.1. SERPENTES

3.1.1.2. CAMUNDONGOS

3.1.2. Plasmas DE OUTROS ANIMAIS VERTEBRADOS

3.1.3. RESINA CROMATOGRÁFICA

3.2. MÉTODOS

3.2.1. Coleta de SANGUE

3.2.2. ISOLAMENTO DA ANTITROMBINA DO PLASMA DA SERPENTE B. JARARACA

3.2.2.1. PURIFICAÇÃO DA ANTITROMBINA DO PLASMA DA SERPENTE B. JARARACA

3.2.2.2. DOSAGEM DAS PROTEÍNAS

3.2.2.3. DOSAGEM DA ANTITROMBINA

3.2.3. MÉtOdOS UTILIZADOS NA CARACTERIZAÇÃo DA ANTITROMBINA DA SERPENTE B. JARARACA

3.2.3.1. AVALIAÇÃO DA ATIVIDADE DA ANTITROMBINA

3.2.3.2. ELETROFORESE EM GEL DE POLIACRILAMIDA CONTENDO SDS 32

3.2.3.3. FOCALIZAÇÃO ISOELÉTRICA 34

3.2.3.4. COLORAÇÃO DO GEL DE POLIACRILAMIDA E DO GEL DE FOCALIZAÇÃO ISOELÉTRICA

3.2.3.5. COLORAÇÃO DO GEL DE POLIACRILAMIDA PARA IDENTIFICAÇÃO GLICOPROTEÍNAS 
3.2.3.8. SEQÜENCIAMENTO DA REGIÃO AMINO-TERMINAL DA ANTITROMBINA DE $B$. JARARACA POR DEGRADAÇÃO DE EDMAN 36

3.2.3.9. ESPECTROMETRIA DE MASSA (MALDI-TOF) 37

3.2.3.10. PRODUÇÃO DE ANTICORPOS POLIClONAIS ANTI-ANTITROMBINA DE $B$. JARARACA 38

3.2.3.11. DETERMINAÇÃO DO TÍTULO DE ANTICORPOS ANTI-ANTITROMBINA DE $B$. JARARACA PELO MÉTODO IMUNOENZIMÁTICO (ELISA) 39

$\begin{array}{ll}\text { 3.2.3.12. "WESTERN BLOTTING" } & 40\end{array}$

4. RESULTADOS $\quad 42$

4.1. ISOLAMENTO DA ANTITROMBINA DO PLASMA DA SERPENTE B. JARARACA 42

4.1.1. DOSAGEM DE ANTITROMBINA 43

4.2. CaRACTERIZAÇÃo BIOQUíMICA DA ANTITROMBINA dO PLASMA DA SERPENTE

B. JARARACA 46

4.2.1. AVALIAÇÃo da ATIVIDADE Da ANTITROMBINA 46

4.2.2. ELETROFORESE EM GEL DE POLIACRILAMIDA CONTENDO SDS 47

4.2.3. FOCALIZAÇÃ̃ ISOELÉTRICA

4.2.4. IDENTIFICAÇÃO DE GLICOPROTEÍNAS

4.2.5. DEGLICOSILAÇÃO

4.2.6. SEQÜENCIAMENTO DA REGIÃO AMINO-TERMINAL DA ANTITROMBINA DE $\boldsymbol{B}$. JARARACA POR DEGRADAÇÃO DE EDMAN

4.2.7. ESPECTROMETRIA DE MASSA (MALDI-TOF)

4.2.8. "WESTERN BLOTTING"

5. DISCUSSÃO

6. CONCLUSÕES

7. RESUMO $\quad 66$

\begin{tabular}{lr} 
8. ABSTRACT & 68 \\
\hline
\end{tabular}

9. APENDICE A - ABREVIATURAS

10. APÊNDICE B - SÍMBOLOS DOS AMINOÁCIDOS

11. REFERÊNCIAS BIBLIOGRÁFICAS 
12. BIOGRAFIA

92 


\section{Introdução}

É possível que a forma alongada do corpo, sem patas e dotado de ágeis movimentos ondulatórios, o olhar fixo, as cores vivas e, definitivamente, a capacidade de algumas espécies de produzir um veneno mortal, tenha feito das serpentes uns dos animais mais temidos e rejeitados pela humanidade. O próprio pavor e aversão que o homem mostra por esses animais devem ter influído decisivamente para alimentar sua ignorância em relação a eles, deixando-os submersos em um universo mítico e fantasioso (Melgarejo, 2003).

Atualmente, há cerca de 2.900 espécies de serpentes no mundo, distribuídas em 465 gêneros e 20 famílias. No Brasil, temos representantes de 9 famílias, 75 gêneros e 321 espécies, ou seja, cerca de $10 \%$ do total de espécies (FrANCO, 2003).

As serpentes distribuem-se por quase todos os ambientes do globo terrestre, com exceção das calotas polares, onde o clima demasiadamente frio impossibilita a vida de vertebrados ectotérmicos (CADLE, 1987).

As serpentes apresentam como características diagnósticas o corpo extremamente alongado sem apêndices locomotores e cintura escapular, perda da sínfise mandibular (perda da sutura óssea das hemimandíbulas no mento, substituída por um ligamento elástico), fechamento lateral da parede da caixa craniana e perda de pálpebras móveis, entre outras características (UNDERWOOD, 1967; Estes et al., 1988; RIPPIEL, 1988; FERRAREZZI, 1994). Esses animais alimentam-se de presas inteiras, que caçam utilizando estruturas quimiossensíveis. São 
exclusivamente carnívoras, predando tanto vertebrados quanto invertebrados (GREENE, 1997). A perda da sínfise mandibular e da cintura escapular, entre outras modificações cranianas, permite a ingestão de presas grandes, com até 3,5 vezes o seu diâmetro (FRANCO, 2003).

\subsection{Bothrops jararaca}

Pertencendo à família Viperidae, o gênero Bothrops possui algumas das espécies mais importantes do ponto de vista médico, já que são responsáveis por cerca de $90 \%$ dos 20.000 acidentes ofídicos anuais que o Brasil registra (MINISTÉRIO DA SAÚDE, 2001).

A espécie B. jararaca ocorre do sul da Bahia ao norte da Argentina e Paraguai, distribuindo-se no Brasil nos estados de Espírito Santo, Minas Gerais, Rio de Janeiro, São Paulo, leste do Mato Grosso do Sul, Paraná, Santa Catarina e Rio Grande do Sul (MELGAREJo, 2003).

É uma espécie predominantemente noturna e terrestre (SAZIMA, 1988). Encontra-se em diversos habitats: florestas tropicais, semi-tropicais, campos abertos e cerrados (SAZIMA, 1992). Ágil, sobe com facilidade em arbustos e telhados baixos, tem grande capacidade adaptativa, ocupando e colonizando tanto áreas silvestres, agrícolas, suburbanas e até urbanas (MELGAREJO, 2003).

O seu padrão de coloração é muito variável, com manchas marrons escuras dispostas em faixas entremeadas por áreas claras, cinzas, oliváceas, amareladas ou beges (CAMPBELL E LAMAR, 
1989). As manchas escuras de formas triangulares distribuem-se em ambos os lados do corpo, de modo que os ápices dos triângulos ficam sobre a linha média dorsal, dispondo-se em oposição total ou parcial, ou justapostos. As manchas claras são mais difusas, mas não há um padrão rígido ao longo do corpo. A parte ventral do corpo é clara, de um bege ligeiramente esverdeado ou amarelado, ou ainda uniformemente acinzentada (figura 1) (SAZIMA, 1992).

O tamanho médio dessas serpentes é de cerca de $1 \mathrm{~m}$, mas os maiores exemplares observados apresentavam 1,5 m; são vivíparas e nascem, principalmente, entre fevereiro e março, em ninhadas compostas de 3 a 35 filhotes (média de 14), medindo em torno de $20 \mathrm{~cm}$ de comprimento. Hoje, esta é uma das espécies brasileiras mais bem conhecidas quanto à biologia, graças aos estudos de IVAN SAZIMA $(1988,1992)$.

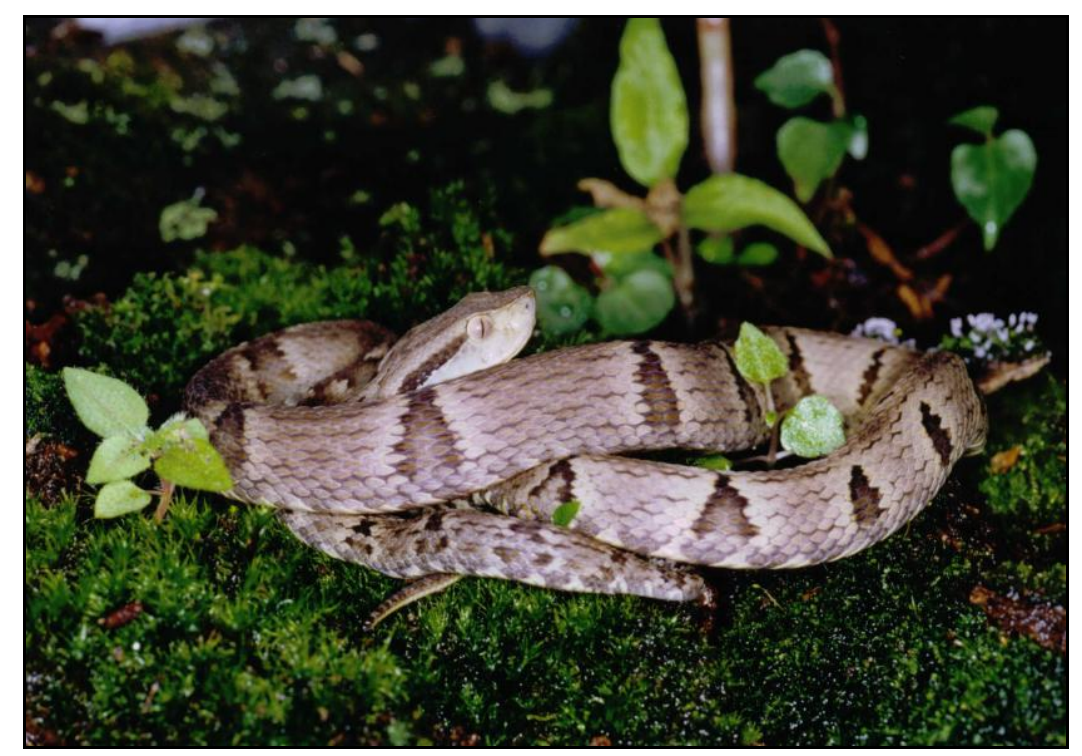

Figura 1. Serpente B. jararaca (cedida por Alexandre Zanotti). 


\subsection{Hemostasia}

A hemostasia é um mecanismo de defesa fundamental presente em todos os vertebrados que envolve dois processos complementares: a formação do coágulo sangüíneo, ou trombo, para impedir a perda de sangue mediante uma injúria vascular, e o processo de dissolução do trombo, ou fibrinólise, após o reparo das células endoteliais. Ambos são processos complexos que envolvem múltiplas interações interdependentes entre plaquetas, células endoteliais, leucócitos e proteínas plasmáticas (GENTRY, 2004).

Estes mecanismos hemostáticos podem ser divididos basicamente em dois estágios: um com a participação dos componentes celulares, conhecido como hemostasia primária, e outro com a participação dos fatores plasmáticos, denominado hemostasia secundária (IwANAGA, 1993). Nos mamíferos, a hemostasia primária ocorre pela interação das plaquetas com os elementos do vaso lesado, resultando na formação de um tampão de plaquetas. Esta interação envolve uma série de eventos que incluem a adesão das plaquetas ao subendotélio, sua ativação e mudança de forma, além da liberação de seu conteúdo granular (corpos densos e $\alpha$-grânulos), com subseqüente formação dos agregados plaquetários estabilizados pela fibrina e retração do coágulo (TRIPLETT, 2000). Numerosos fatores plasmáticos, proteínas tissulares, cofatores, serinoproteases, fosfolipídios e íons cálcio participam no processo da hemostasia secundária (IWANAGA, 1993)

O endotélio mantém a fluidez do sangue através da inibição da coagulação sangüínea e da agregação plaquetária e da promoção da fibrinólise. As células endoteliais também atuam como 
uma barreira física que separa as células sangüíneas e os fatores de coagulação plasmáticos de elementos reativos presentes no subendotélio. Esses elementos incluem proteínas adesivas como o colágeno e o fator de von Willebrand, que promovem a adesão plaquetária, e o fator tissular, uma proteína de membrana presente em fibroblastos e macrófagos que inicia a cascata de coagulação. Quando os vasos sangüíneos são lesionados, eles se contraem direcionando o sangue para o local da injúria vascular, onde este é exposto às estruturas subendoteliais que estimulam a formação do tampão plaquetário através da indução da adesão e agregação plaquetária e da ativação da coagulação sangüínea (COLMAN et al., 1994).

Quando as plaquetas são estimuladas pelo colágeno subendotelial as glicoproteínas IIb e IIIa são expostas em sua membrana, as quais têm a propriedade de se ligar ao fibrinogênio e ao fator de von Willebrand, cofatores no recrutamento e na agregação plaquetária. A secreção de proteínas dos $\alpha$-grânulos é mediada pela síntese de tromboxano $\mathrm{A}_{2}$, pela fosforilação de proteínas específicas e pela translocação de cálcio intracelular. Cofatores protéicos como o fator $\mathrm{V}$ atuam como sítio de ligação de complexos enzimáticos na superfície das plaquetas, acelerando assim a ativação do fator $\mathrm{X}$ e da protrombina. O resultado é a formação de trombina, a qual amplifica sua própria geração através da conversão dos fatores V e VIII em cofatores ativados, estimulando assim a secreção plaquetária (COLMAN et al., 1994).

Com exceção do fator XIII, que é uma transglutaminase, todas as enzimas envolvidas na coagulação sanguiínea são zimogênios de serinoproteases. As serinoproteases da coagulação são convertidas da forma inativa para a forma ativa, simbolizada pelo número correspondente ao fator seguido pela letra (a), por proteólise limitada de uma ou duas ligações peptídicas (FURIE E FURIE, 1992). Algumas dessas serinoproteases são dependentes de vitamina K para sua 
biossíntese, ou seja, para alcançar sua forma funcional sofrem uma modificação pós-traducional em resíduos de ácido glutâmico da região amino-terminal, os quais são modificados em ácido $\gamma$ carboxiglutâmico. Estes resíduos são importantes para a ligação destas proteínas aos íons cálcio, que mantêm a estrutura desses fatores e também permite a ligação destes aos fosfolipídeos expostos na membrana das plaquetas ativadas (ROBERTS E LOZIER, 1992). Duas outras importantes proteínas nesse processo são os fatores V e VIII da coagulação sangüínea, que são cofatores dos fatores X e IX, respectivamente. Estes cofatores são ativados pela trombina e amplificam a atividade catalítica das enzimas correspondentes na superfície negativamente carregada das plaquetas (ToOLE et al., 1986).

A cascata de coagulação pode ser didaticamente dividida em duas vias de ativação, a via extrínseca e a via intrínseca, entretanto, essas duas vias são fisiologicamente interdependentes. A primeira via clássica de ativação da cascata de coagulação, denominada via extrínseca, inicia-se pela exposição do fator tissular mediante uma injúria tissular, ou seja, uma ação externa ao organismo. A via intrínseca, por outro lado, é um mecanismo complementar que se inicia após a ativação do sistema de contato (TAPPER E HERWALD, 2000). Ela envolve o fator XII, o cininogênio de alta massa molecular (HMWK), a precalicreína e o fator XI. Alguns autores consideram que a via extrínseca seja importante para o início do processo de coagulação e que a via intrínseca esteja relacionada com a sua manutenção (DAVIE et al., 1991). A deficiência do fator XII, da pré-calicreína e do cininogênio de alto peso molecular não é associada a problemas de sangramento, enquanto a deficiência de fator XI causa distúrbios hemostáticos leves (DAHLBACK, 2000). Dessa forma, a importância do sistema de contato para a cascata de coagulação é questionável. Entretanto, Renne et al. (2005) observaram que o fator XII é essencial para a formação e para a estabilização do coágulo (RENNE et al., 2005). 
O início da coagulação sangüínea associado a danos nos vasos sanguíneos envolve a exposição do fator tissular na superfície das células danificadas. O fator tissular se liga tanto ao zimogênio quanto à forma ativa do fator VII ( $\mathrm{VII}_{\mathrm{a}}$ ), sendo que uma pequena quantidade de fator VII está presente no sangue em sua forma ativa. O complexo fator tissular-fator $\mathrm{VII}_{\mathrm{a}}$ desencadeia a coagulação sangüínea convertendo os fatores IX e $\mathrm{X}$ para suas formas ativas $\left(\mathrm{IX}_{\mathrm{a}}\right.$ e $\mathrm{X}_{\mathrm{a}}$ ) (KIRCHHOFER E NEMERSON, 1996). A amplificação da cascata, pela retroalimentação positiva, ocorre quando o fator VII ligado ao fator tissular é ativado pelos fatores $\mathrm{VII}_{\mathrm{a}}, \mathrm{IX}_{\mathrm{a}}$ e $\mathrm{X}_{\mathrm{a}}$. Os fatores $\mathrm{IX}_{\mathrm{a}}$ e $\mathrm{X}_{\mathrm{a}}$ podem permanecer associados ao fator tissular ligado às células ou difundem-se no sangue e ligam-se às superfícies próximas das plaquetas ativadas, que formam o tampão plaquetário. A ativação das plaquetas promove a exposição dos fosfolipídeos carregados negativamente, que têm alto potencial de ligar fatores de coagulação e reunir os complexos enzima-cofator, que são essenciais para uma eficiente ativação da coagulação sangüínea (ZWAAL et al., 1998). Além disso, a reunião de complexos enzima-cofator na superfície das plaquetas aumenta a concentração local dos componentes envolvidos na coagulação e neutraliza a regulação exercida por mecanismos anticoagulantes (DAHLBACK, 2000).

A protrombina é transformada em trombina pelo complexo protrombinase, composto pelo fator $\mathrm{X}_{\mathrm{a}}$ e seu cofator (fator $\mathrm{V}_{\mathrm{a}}$ ) ligados aos fosfolipídios na presença de cálcio. Os fatores que ativam o fator $\mathrm{V}$ são o $\mathrm{X}_{\mathrm{a}}$ e a trombina. Esta última também amplifica a cascata da coagulação ativando os fatores VIII e IX. Após sua ativação, o fator VIII ${ }_{a}$ forma um complexo com o fator $\mathrm{IX}_{\mathrm{a}}$ na superfície das plaquetas, que juntamente com fosfolipídeos e íons cálcio, é denominado complexo tenase, que ativa o fator X. A ativação do fator XI pela trombina é outro mecanismo de 
amplificação desta reação, resultando na geração adicional de fator $\mathrm{IX}_{\mathrm{a}}$, que ativa o fator $\mathrm{X}$ (GAILANI E BROZE, 1991).

A formação do coágulo ocorre quando o fibrinogênio é convertido pela trombina em fibrina pela clivagem de dois peptídeos, liberando assim dois pequenos peptídeos aminoterminais, o fibrinopeptídeo A e o fibrinopeptídeo B (FURIE E FURIE, 1992). A trombina também é responsável pela ativação do fator XIII, que estabiliza o coágulo pela formação de ligações covalentes entre os monômeros de fibrina (DAVIE et al., 1991).

A trombina é uma enzima chave da coagulação sanguínea. Sua atividade procoagulante é responsável pela conversão do fibrinogênio em monômeros de fibrina e ativação do fator XIII. A trombina também ativa as plaquetas e os fatores V e VIII, cofatores da cascata de coagulação, acelerando assim sua própria geração e proporcionando uma resposta rápida à injúria vascular. Entretanto, a natureza autocatalítica da trombina oferece alguns riscos, tornando indispensável o controle detalhado da sua atividade a fim de prevenir a deposição anormal de fibrina na vasculatura (DAVIE et al., 1991).

A versatilidade da trombina existe em função da sua estrutura: além do sítio ativo, ela possui vários sítios adicionais chamados exossítios ou subsítios de centros de reconhecimento para substratos e receptores. O exossítio I interage com o fibrinogênio, a fibrina, a hirudina, a trombomodulina e o receptor de trombina, enquanto o exossítio II interage com a heparina e com o fragmento de trombina F2, prevenindo a inibição da trombina durante os estágios iniciais da coagulação (STUBBS E BODE, 1994). 
A regulação da coagulação é exercida em cada nível das vias de ativação, pela presença das enzimas na forma inativa (zimogênios), pela inibição das enzimas ou pela modulação da atividade de seus cofatores.

Um desses inibidores é o inibidor da via do fator tissular (TFPI), presente no plasma em uma concentração relativamente baixa, que tem como alvo o fator $\mathrm{X}_{\mathrm{a}}$ e o complexo fator tissularfator VII $_{\mathrm{a}}$-fator $\mathrm{X}_{\mathrm{a}}$ (RAPAPORT, 1991).

Muitas das enzimas geradas durante a ativação da cascata de coagulação são inibidas pela antitrombina, um inibidor de serinoproteases. A antitrombina inibe preferencialmente enzimas livres, enquanto as enzimas que fazem parte dos complexos protrombinase e tenase são menos acessíveis ao inibidor. O papel fisiológico da antitrombina é limitar o processo de coagulação ao local de injúria vascular (DAHLBACK, 2000).

A proteína $\mathrm{C}$ regula o sistema de coagulação através da modulação da atividade de dois cofatores, os fatores $\mathrm{V}_{\mathrm{a}}$ e $\mathrm{VIII}_{\mathrm{a}}$ (DAHLBACK, 1995). A proteína $\mathrm{C}$, um zimogênio vitamina $\mathrm{K}$ dependente, é ativada pela trombina na superfície das células endoteliais intactas, onde a trombina encontra-se ligada a trombomodulina, uma proteína de membrana. Dessa forma, a trombina apresenta tanto atividade procoagulante quanto anticoagulante, dependendo do contexto em que foi gerada. Em locais de lesão vascular ocorre o predomínio de sua atividade procoagulante, enquanto que em um sistema vascular intacto atua como um inibidor da coagulação, desde que se liga à trombomodulina e ativa a proteína $\mathrm{C}$. A proteína $\mathrm{C}$ ativa cliva os fatores $\mathrm{V}_{\mathrm{a}}$ e $\mathrm{VIII}_{\mathrm{a}}$, quando estes encontram-se ligados à membranas fosfolipídicas, inibindo assim o sistema de coagulação. Outra proteína vitamina K-dependente, a proteína S, atua como cofator 
da proteína C. A proteína $\mathrm{C}$ ativa e a proteína $\mathrm{S}$ formam um complexo capaz de clivar os fatores $\mathrm{V}_{\mathrm{a}}$ e VIII $_{\mathrm{a}}$ mesmo quando estes fazem parte do complexo tenase e protrombinase (DAHLBACK, 1995).

A proteína $\mathrm{C}$, entretanto, não cliva o fator VIII intacto devido à sua ligação com o fator von Willebrand, o qual impede a ligação do fator VIII aos fosfolipídeos de membrana. Em contraste, o fator $\mathrm{V}$ se liga a esses fosfolipídeos da mesma forma que o fator $\mathrm{V}_{\mathrm{a}}$, o que permite sua inativação pela proteína $\mathrm{C}$. Como conseqüência, este fator V inativado atua em sinergia com a proteína $\mathrm{S}$ como cofator da proteína $\mathrm{C}$ ativa na degradação do fator $\mathrm{VIII}_{\mathrm{a}}$. Assim, o fator $\mathrm{V}$ pode atuar em favor da coagulação, quando ativado pelo fator $X_{a}$ e pela trombina, ou em favor da anticoagulação, quando clivado proteoliticamente pela proteína C ativa (DAHLBACK, 1999).

A fibrinólise é um processo que limita a formação do coágulo e constitui também um mecanismo de reparo, juntamente com a renovação celular e o reestabelecimento da vasculatura. O sistema fibrinolítico se assemelha à cascata de coagulação por envolver a ativação seqüencial de zimogênios para suas formas enzimáticas ativas, por ser potencializado e inibido por retroalimentação e por ser modulado por uma série de inibidores (COLMAN et al., 1994).

A fibrinólise pode ser definida como a degradação da fibrina, mediada pela plasmina. $\mathrm{O}$ sistema fibrinolítico ou sistema plasminogênio/plasmina é composto por diversas proteínas (proteases plasmáticas e inibidores), que regulam a geração da plasmina, uma enzima ativa gerada a partir de uma proenzima inativa, o plasminogênio, que tem como função degradar a fibrina e ativar metaloproteases da matriz extracelular (COLLEN, 1999). 
As enzimas do sistema fibrinolítico são serinoproteases, ao passo que os inibidores da fibrinólise são membros da família das serpinas (inibidores de serinoproteases). São conhecidos dois ativadores fisiológicos do plasminogênio: o ativador de plasminogênio do tipo tecidual (tPA, "tissue-type plasminogen activator") e o ativador de plasminogênio do tipo uroquinase (uPA, "urokinase-type plasminogen activator"). Os dois ativadores têm alta especificidade de ligação com seu substrato (plasminogênio) e promovem a hidrólise de uma única ligação peptídica (Arg560-Val561), que resulta na formação de uma serinoprotease ativa, a plasmina (FRANCO, 2001).

Embora a plasmina degrade não somente a fibrina, mas, também, o fibrinogênio, o fator $\mathrm{V}$ e o fator VIII, em condições fisiológicas a fibrinólise apresenta-se como um processo altamente específico para a fibrina, com ativação localizada e restrita, removendo assim o excesso de fibrina intravascular de modo equilibrado. Essa especificidade é resultante de interações moleculares específicas entre os ativadores de plasminogênio, o plasminogênio, a fibrina e os inibidores da fibrinólise (FRANCO, 2001).

A inibição do sistema fibrinolítico ocorre pela ação de inibidores específicos para o plasminogênio (PAIs, "plaminogen activator inhibitors", cujo principal representante é o PAI-I) e para a plasmina ( $\alpha_{2}$-antiplasmina) (FRANCO, 2001).

Outro importante inibidor da fibrinólise é o TAFI ("thrombin-activable fibrinolyses inhibitor" ou inibidor da fibrinólise ativado pela trombina). O TAFI é ativado pela trombina, pela tripsina e pela plasmina e, na sua forma ativa, é capaz de inibir a fibrinólise por remover resíduos de lisina da molécula de fibrina durante o processo de degradação do coágulo, suprimindo assim 
a capacidade da fibrina de ativar o plasminogênio. Curiosamente, o principal ativador fisiológico do TAFI é a trombina, ligada à trombomodulina (complexo que também ativa o sistema da proteína C). Dessa forma, o TAFI representa um ponto de conexão entre o sistema de coagulação e o sistema fibrinolítico (BAJZAR, 2000).

O esquema da cascata de coagulação e alguns de seus inibidores bem como do sistema fibrinolítico pode ser visto na figura 2. 


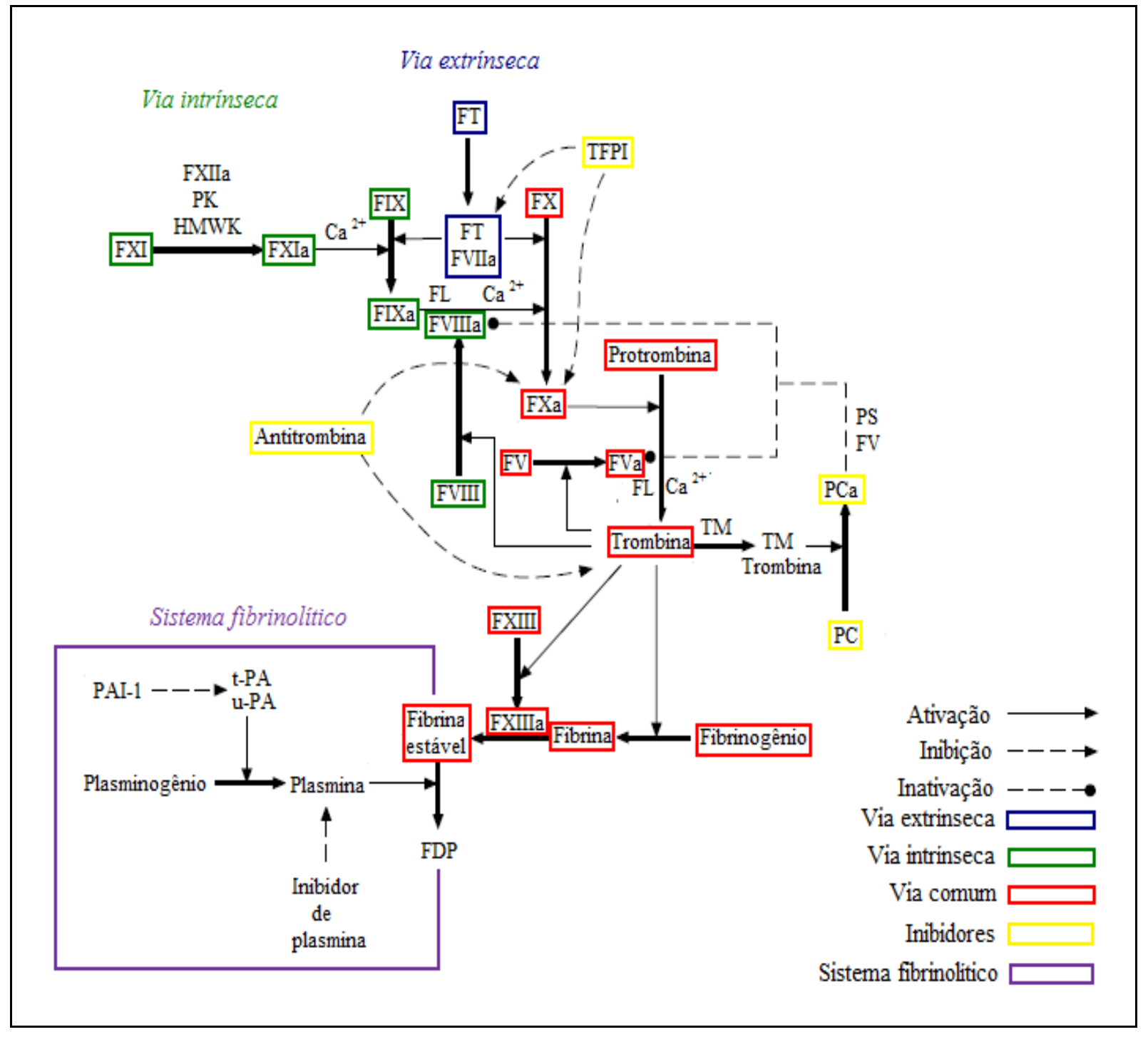

Figura 2. Esquema da cascata de coagulação e da fibrinólise, indicando alguns mecanismos inibitórios. 


\subsection{Inibidores de serinoproteases (serpinas)}

Muitas das proteínas envolvidas nas vias de coagulação e fibrinólise são enzimas proteolíticas e, por isso, suas atividades devem ser controladas a fim de evitar que ofereçam riscos ao organismo que têm como objetivo proteger. O risco potencial que oferecem ao organismo foi minimizado pela evolução de uma série de proteínas que possuem a habilidade de diminuir a atividade proteolítica de determinadas enzimas (SALVESEN, 1994).

Um grande número de proteases é encontrado nos mamíferos. Essas enzimas participam de diversos processos como digestão dos alimentos, destruição da matriz extracelular, cicatrização dos tecidos, renovação e reorganização tecidual, processamento de hormônios e enzimas, bem como interferem em vias inflamatórias e em cascatas de reações que levam à ativação do sistema complemento, da cascata de coagulação e da fibrinólise (TwINING, 1994).

Apesar do grande número de proteases existentes, elas podem ser classificadas, dependendo do mecanismo que utilizam para hidrolizar ligações peptídicas, em apenas quatro classes, denominadas: cisteino, aspártico, metalo e serinoproteases. Dessas classes, o maior grupo é o das serinoproteases. Esse grupo inclui muitas das enzimas digestivas (como a tripsina e a quimotripsina), as proteases envolvidas na coagulação e na fibrinólise e aquelas que compõem o sistema complemento (BARRETT, 1986).

Inibidores específicos evoluíram para limitar a atividade proteolítica de cada um desses grupos de proteases. Os inibidores plasmáticos de proteases constituem, em quantidade, o terceiro 
maior grupo funcional de proteínas no plasma humano, vindo após a albumina e as imunoglobulinas (ROBERTS et al., 1995). Se excluirmos os dois primeiros grupos, cerca de $20 \%$ das proteínas plasmáticas que restam são inibidores de proteases (BARRETT, 1986).

Enquanto quantidades significativas de cisteino e metaloproteases estão presentes no plasma e em outros fluidos biológicos, a grande maioria dos inibidores regula a atividade das serinoproteases. Existem, pelo menos, quatro famílias de inibidores de serinoproteases nos mamíferos: as serpinas, os tipo Kunitz, os tipo Kazal e as leuco-proteases (TRAVIS E SALVESEN, 1983).

Embora essas famílias apresentem diferenças quanto à estrutura, muitos dos inibidores de serinoproteases interagem com suas enzimas alvo de acordo com o seguinte mecanismo: ocorre a ligação do sítio ativo da protease com o sítio reativo do inibidor e a quebra de uma ligação peptídica dentro desse sítio para formar um inibidor modificado. O sítio reativo do inibidor é uma região semelhante ao substrato da enzima e, dessa forma, o inibidor de serinoprotease atua como um pseudo-substrato (TRAVIS E SALVESEN, 1983).

Apesar de o nome serpinas originar-se da abreviação "serine proteinase inhibitors" (“serpin”) (CARREL, 1985), é importante salientar que existem inibidores de serinoproteases que não pertencem a essa família, assim como existem serpinas que não são inibidores de proteases, porque a classificação desta família foi estabelecida segundo a homologia da estrutura primária das proteínas (RoBERTs et al., 1995). 
As serpinas estão amplamente distribuídas entre os seres vivos, desde bactérias termófilas (IRVING et al., 2002) a mamíferos (SILVERMAN et al., 2001), estando ausentes em fungos e em clorófitas, apesar de presentes em plantas superiores (IRVING et al., 2000). Apesar da grande variedade de funções desempenhadas pelas serpinas e do fato de serem encontradas em organismos tão diversos (MARSHALL, 1993), a família das serpinas é composta por um grupo de proteínas altamente conservadas. Essas proteínas são constituídas, geralmente, por 370 a 390 aminoácidos e apresentam massas moleculares entre 45 e $100 \mathrm{kDa}$, dependendo do grau de glicosilação e da capacidade de formar dímeros (ROBERTS et al., 1995).

As diversas funções atribuídas às serpinas estão sumarizadas na figura 3.

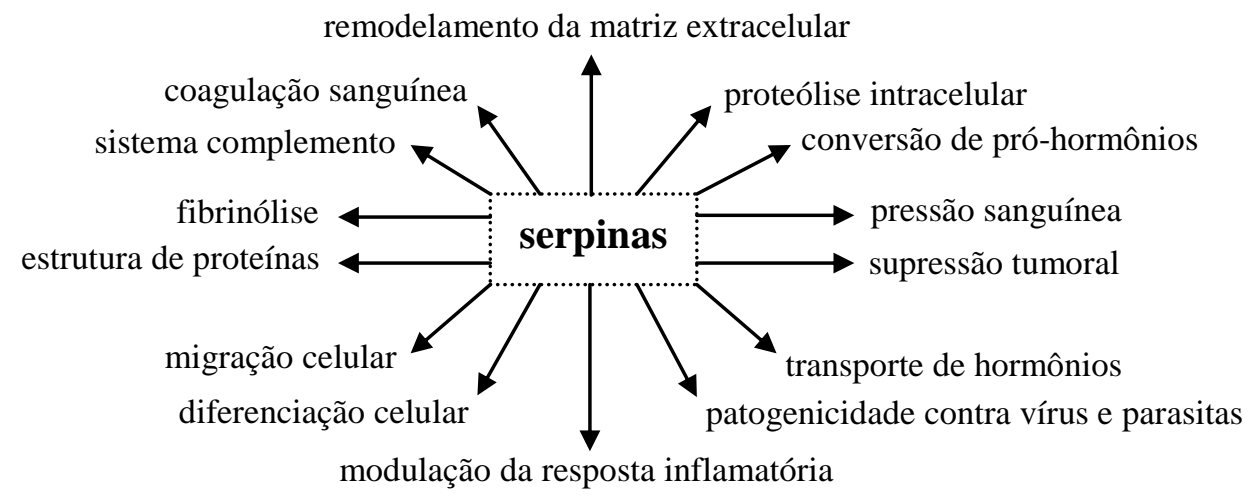

Figura 3. As múltiplas funções regulatórias das serpinas (Potempa et al., 1994). 


\subsection{Antitrombina}

A antitrombina, também chamada antitrombina-III, é o principal inibidor fisiológico da trombina, responsável por aproximadamente $80 \%$ da atividade inibitória sobre essa enzima (PERRY, 1994).

Em humanos, a antitrombina é uma glicoproteína plasmática de cadeia única, com massa molecular de $58 \mathrm{kDa}$, membro da família das serpinas. Essa proteína é sintetizada no fígado (LEON et al., 1983) e em condições normais está presente no plasma em uma concentração de cerca de $150 \mu \mathrm{g} / \mu \mathrm{L}$ (CONARD et al., 1983), com meia vida de 3 dias (Collen et al., 1977). A estrutura primária da antitrombina humana é composta por 432 resíduos de aminoácidos, dos quais seis são cisteínas que formam três pontes dissulfeto (PETERSEN, 1979). A molécula contém quatro sítios de glicosilação, podendo ser glicosilada em todos esses sítios (antitrombina $\alpha-$ cerca de $90 \%$ do total de moléculas) ou em apenas três desses sítios (antitrombina $\beta$ - cerca de 10\% do total de moléculas) (STEIN E CARRELl, 1995). A antitrombina $\beta$ não possui a cadeia de carboidratos no resíduo Asn135, o qual está situado próximo ao sítio de ligação à heparina, o que resulta em uma maior afinidade pela heparina do que a encontrada para a antitrombina $\alpha$ (BRENNAN et al., 1987).

A estrutura cristalográfica da antitrombina está representada na figura 4 e a localização de seus domínios funcionalmente importantes como o sítio reativo, os sítios de ligação à heparina e as pontes dissulfeto estão representados na figura 5. 


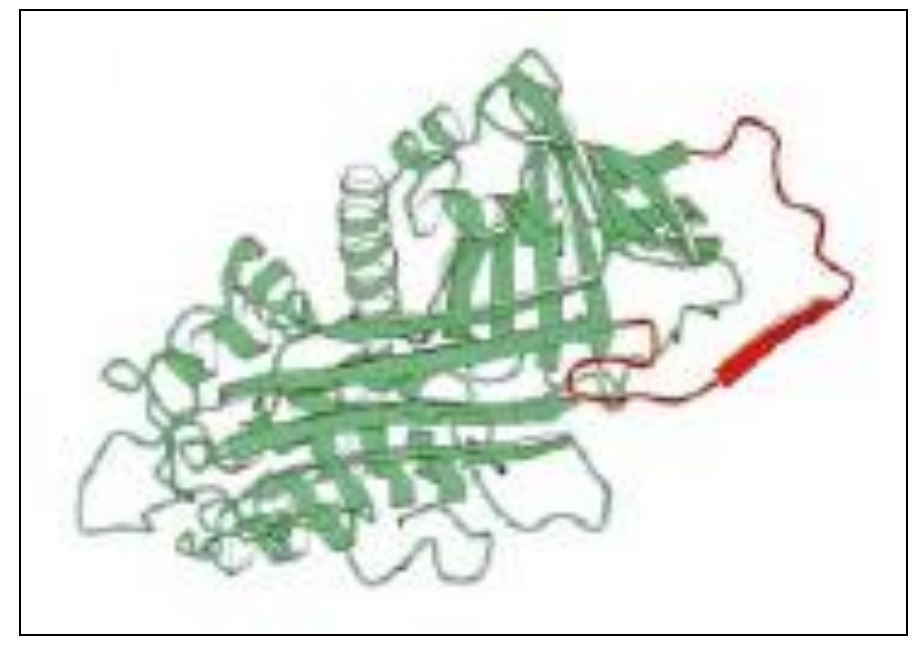

Figura 4. Estrutura cristalográfica da antitrombina, com destaque para o sítio reativo (em vermelho) (CARRELl E GoOPtu, 1998).

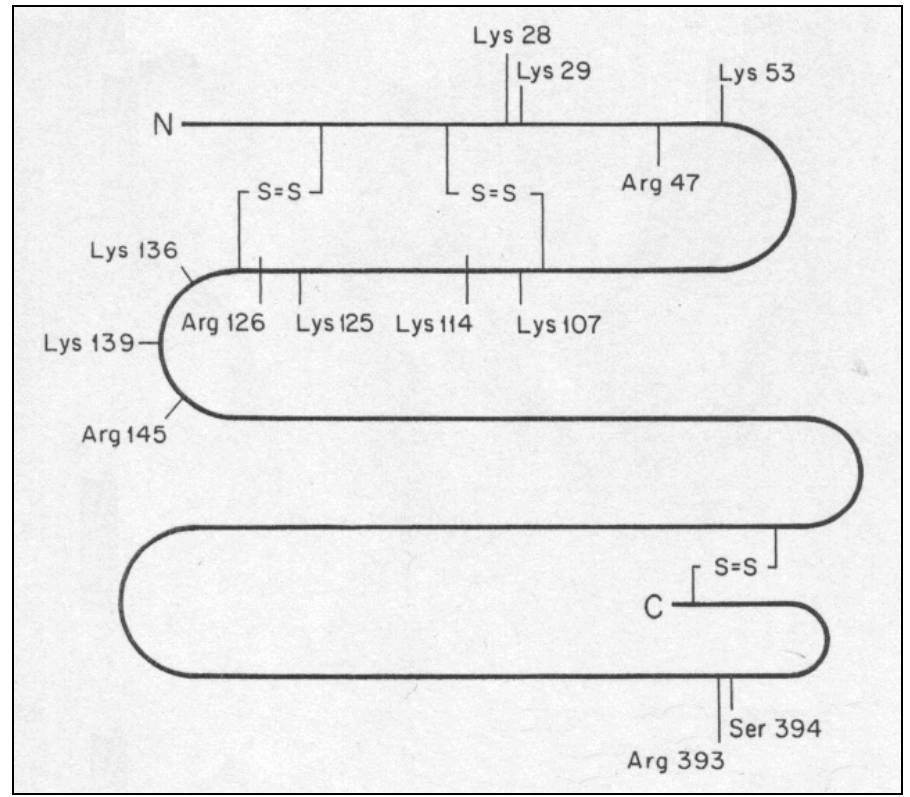

Figura 5. Sítios funcionalmente importantes da antitrombina. O sítio reativo é composto pelos resíduos Arg393 - Ser394 e os resíduos de lisina e arginina são os sítios de ligação à heparina (ROSENBERG, 1994). 
A antitrombina é o principal inibidor da trombina, do fator $\mathrm{IX}_{\mathrm{a}}$ e do fator $\mathrm{X}_{\mathrm{a}}$, mas também inativa outras serinoproteases, envolvias ou não na coagulação sangüínea, como o fator $\mathrm{XI}_{\mathrm{a}}$, o fator $\mathrm{XII}_{\mathrm{a}}$, a plasmina, a calicreína e a enzima $\mathrm{C} 1$ do sistema complemento (Rosenberg et al., 1975; Kurachi et al., 1976; Summaria et al., 1977). Alguns estudos sugerem que o sistema heparina-antitrombina é a principal via de neutralização da maioria dos fatores ativados que compõem a via intrínseca da coagulação sangüínea, exceto para o fator $\mathrm{XII}_{\mathrm{a}}$, que é inibido principalmente pelo inibidor C1, mesmo na presença da serpina (ROSENBERG, 1994).

A inibição pela antitrombina envolve a formação de um complexo estável eqüimolar (1:1) entre o sítio ativo da serinoprotease e o sítio reativo da antitrombina, o qual a protease reconhece inicialmente como um substrato. Com a clivagem de uma ligação do sítio reativo da antitrombina (Arg393-Ser394) pela sua enzima alvo, ocorre uma mudança conformacional no inibidor que captura a protease (que se liga covalentemente ao inibidor) e corrompe sua tríade catalítica, o que causa sua inibição irreversível (ROSENBERG E DAMUS, 1973).

As interações protease-inibidor são lentas, apesar de aumentarem dramaticamente na presença de certos polissacarídeos sulfatados conhecidos como glicosaminoglicanas (GAGs) (BOURIN E LINDAHL, 1993). Acredita-se que GAGs intravasculares, principalmente o heparansulfato, se ligam à antitrombina e à trombina e assim catalisam a reação antitrombinatrombina. Isto permitiria o aumento seletivo da atividade da antitrombina na interface endotéliosangue, onde as enzimas de coagulação são geradas (ROSENBERG, 1989). Quando presentes, os GAGs se ligam aos resíduos de lisina e arginina positivamente carregados localizados na região amino-terminal da antitrombina (ROSENBERG E DAMUS, 1973), e aceleram a geração do complexo 
enzima-inibidor através da indução de mudanças conformacionais no sítio reativo da molécula de antitrombina (GETTINS et al., 1993), o que torna o inibidor mais acessível à interação com a trombina ou com outras enzimas da coagulação (JORDAN et al., 1980). Além disso, a heparina pode neutralizar regiões catiônicas presentes na antitrombina e na trombina (SALVESEN, 1994). O modelo do complexo antitrombina-trombina-heparina está representado na figura 6.

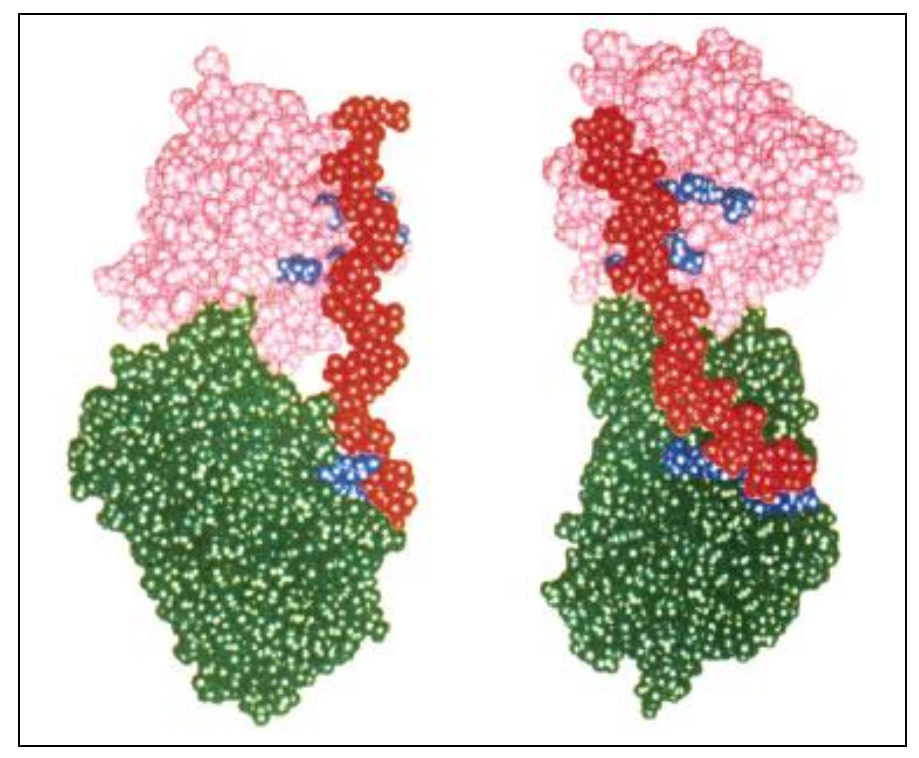

Figura 6. Modelo do complexo antitrombina-trombina-heparina, construído através das estruturas das proteínas obtidas por raio-X. Em verde, antitrombina; em rosa, trombina; em vermelho, heparina e em azul, sítios de ligação à heparina (GROOTENHUIS et al., 1995).

A heparina é uma GAG altamente sulfatado encontrado em todos os animais localizados acima dos limulídeos na escala filogenética. Em mamíferos, é sintetizada pelos mastócitos, e, portanto, é encontrada em diversos órgãos, como fígado, coração, pulmões, rins e intestino (ENGELBERG, 1978). A ligação da heparina à antitrombina é responsável por uma aceleração de aproximadamente 1.000 vezes na formação do complexo enzima-inibidor (BROZE E MAJERUS, 
1980; JORDAN ET AL., 1980). A heparina comercial é uma mistura de GAGs extraídas principalmente da mucosa intestinal de bovinos e suínos, sendo um importante fármaco anticoagulante.

As células endoteliais de mamíferos sintetizam uma outra GAG tipo heparina, o heparansulfato, encontrado nas superfícies celulares e na matriz intercelular (ROSENBERG, 1994).

Dessa forma, pequenas quantidades de antitrombina encontram-se, geralmente, ligadas às GAGs associadas às células endoteliais. Esses polissacarídeos permitem que o inibidor seja seletivamente ativado na interface endotélio-sangue, onde as enzimas da coagulação sangüínea são normalmente geradas. Assim, a antitrombina neutraliza essas enzimas hemostáticas e protege o endotélio da formação de trombos intravasculares (ROSENBERG, 1994).

A figura 7 apresenta um modelo simplificado de como a heparina catalisa a formação do complexo irreversível entre a trombina $\left(\mathrm{FII}_{\mathrm{a}}\right)$ e a antitrombina $(\mathrm{AT})$. (H) simboliza o sítio de ligação à heparina e (R) é o sítio reativo da antitrombina, normalmente em uma conformação favorável à inibição da protease. (P) é o segmento de ligação à antitrombina presente na heparina. A ligação ao (P) induz uma mudança conformacional na antitrombina que facilita a reação antitrombina-trombina. A trombina se liga à heparina de uma maneira não-específica e se desloca através da cadeia até encontrar a antitrombina. A afinidade da heparina pelo complexo trombinaantitrombina é muito menor que pela trombina livre. A heparina então se dissocia do complexo trombina-antitrombina, o qual é rapidamente removido da circulação pelo fígado (PIZZO, 1989). 


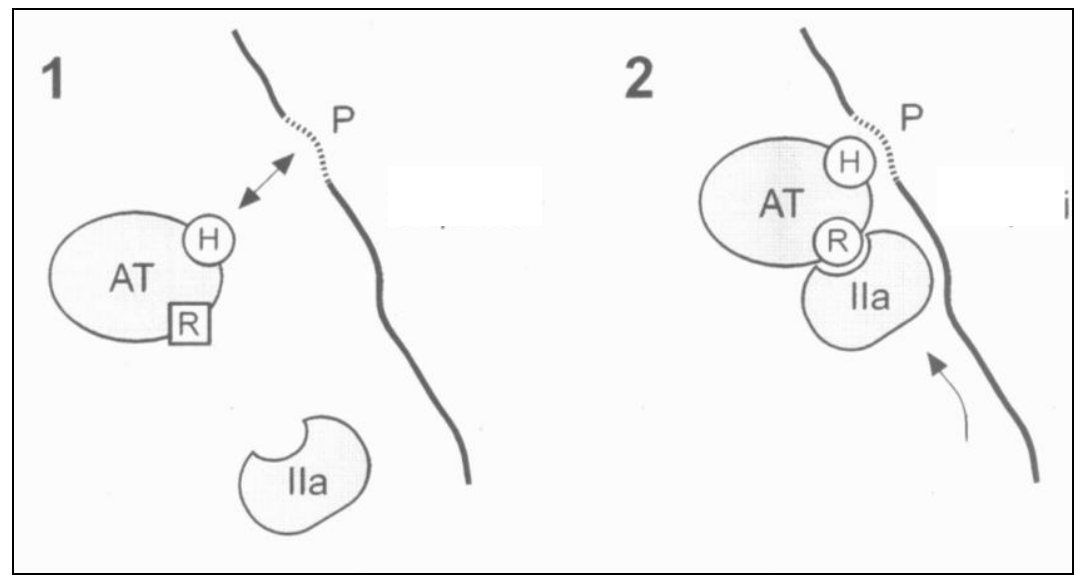

Figura 7. Modelo simplificado descrevendo como a heparina catalisa a formação do complexo trombinaantitrombina. (AT) antitrombina, $\left(\mathrm{II}_{\mathrm{a}}\right)$ trombina, $(\mathrm{H})$ sítio de ligação da heparina, $(\mathrm{R})$ sítio reativo, $(\mathrm{P})$ segmento da molécula de heparina que se liga à antitrombina (CHROMOGENIX, 1995).

\subsection{Hemostasia comparada}

Os estudos envolvendo a coagulação sanguínea de humanos foram estimulados por condições patológicas e pela descoberta de deficiências hemostáticas. Em contraste com a extensa literatura acerca da coagulação humana e suas desordens, pouco se conhece sobre o sistema hemostático de não mamíferos, em que o conhecimento dos mecanismos de coagulação e reparação de tecido é, principalmente, morfológico, com poucas informações bioquímicas (IwANAGA, 1993). Entretanto, o estudo dos aspectos evolutivos da coagulação sanguiínea pode contribuir para a elucidação da sua complexidade gradual. Além disso, estudos comparativos podem fornecer evidências de mecanismos alternativos para a coagulação sangüínea (NAHAS et al., 1981). 
Sabe-se, por exemplo, que em todos os celomados existe a participação de células ou de seus fragmentos no mecanismo de coagulação, como os amebócitos nos limulídeos, os hemócitos nos crustáceos, os trombócitos nos peixes, anfíbios, répteis e aves, além das plaquetas nos mamíferos. Além disso, em aracnídeos e vertebrados a formação do coágulo ocorre após injúria vascular, a qual inicia uma cascata de reações enzimáticas que resultam na conversão de uma proteína solúvel em um polímero insolúvel (IWANAGA, 1993; THEOPOLD et al., 2002). Em todos os vertebrados, a formação do coágulo envolve o fator tissular, a protrombina e o fibrinogênio. Em contraste, esse sistema não é encontrado em invertebrados (DOOLITTLE, 1993).

Como essa complexa cascata de reações não pode ter surgido de uma só vez, acredita-se que o sistema de coagulação de mamíferos seja resultado de uma série de duplicações gênicas (JiAng E DoOlitTle, 2003). Resultados obtidos através da comparação da seqüência de aminoácidos das serinoproteases envolvidas na coagulação sangüínea sugeriram que certos fatores de coagulação (particularmente os que compõem o sistema de contato) devem ter surgido mais recentemente no processo evolutivo (DOOLITTLE E FENG, 1987). De fato, um estudo recente de PonCZeK et al. (2008) demonstrou, através da análise do genoma de algumas classes de animais, que o fator XII está ausente em lampréias e em alguns peixes, surgindo inicialmente em anfíbios, estando, porém, ausente em galinhas, sugerindo uma perda deste gene em algumas espécies de aves durante a evolução filogenética. Por outro lado, o fator XI e a pré-calicreína estão ausentes em lampréias, peixes, anfíbios, aves e ornitorrincos, sendo encontrados a partir de marsupiais na escala evolutiva.

Os estudos da coagulação comparada de peixes (LEWIS, 1972) mostraram a ausência de atividade do fator XII, que também foi observada em cetáceos (RoBINSON et al., 1969; SAITO et 
al., 1976). A ausência do fator XII também foi descrita para aves (DIDISHEIM et al., 1959; ERDRÖS, 1967).

Sabe-se que em peixes a trombina é gerada por vias que envolvem fatores dependentes de vitamina K e que a estabilização do coágulo é dependente do fator XIII (DAVIDSON et al., 2003). JAGADEESWARAN E SHEEHAN (1999), estudando a coagulação sangüínea de zebrafish (Danio rerio), demonstraram a presença das vias intrínseca e extrínseca, dos fatores II (protrombina) e X, da proteína $\mathrm{C}$, da antitrombina e do cofator de heparina II, sugerindo que as principais vias de coagulação e anticoagulação apresentam-se conservadas entre algumas espécies de peixes e mamíferos, apesar da distância evolutiva entre essas duas classes de animais.

FROST et al. (1999) demonstraram que a coagulação sangüínea de avestruzes (Struthio camelus) é mais lenta que a das demais aves devido à ausência dos fatores VII, X, IX e XI da coagulação, além do fator XII, e baixas concentrações do fator II e de calicreína. Entretanto, os níveis de antitrombina e $\alpha_{2}$-antiplasmina apresentaram-se dentro dos níveis normais determinados para mamíferos, contribuindo para o prolongamento do tempo de coagulação. Esses autores sugerem que o sistema de coagulação presente em avestruzes seria um sistema intermediário entre o de aves e o de répteis.

Em algumas espécies de répteis, verificou-se a presença da atividade do fator XII (BELAMARICH E ESKRIDGE, 1963; ERDRÖS, 1967), enquanto que em outras não (FANTL, 1961). Além da ausência desse fator nesses animais, também foram relatados níveis baixos de atividade dos fatores VIII e IX (DiDISHEIM et al., 1959; FANTL, 1961), o que tornaria a ativação da via 
intrínseca da coagulação mais lenta. Entretanto, RATNOFF et al. (1990) sugeriram a existência de vias análogas às vias intrínseca e extrínseca da coagulação presentes em mamíferos.

Outro aspecto também observado é que o tempo de coagulação dos répteis é mais longo que o dos mamíferos, anfíbios e elasmobrânqueos: entretanto, adicionando-se extrato tissular ao sangue de répteis ocorre uma coagulação rápida (ARCHER, 1970), mostrando que o sistema extrínseco é funcional como nos mamíferos. Este resultado indica diferenças no mecanismo de ativação da coagulação dos répteis principalmente quanto à via intrínseca da coagulação, que parece ser mais lenta que no homem (HACKETT E HANN, 1967; NAHAS et al., 1981).

Além da ausência de alguns fatores de coagulação sanguínea nesses animais, outro fator que pode contribuir para uma coagulação mais lenta é a presença de anticoagulantes naturais, como já observado no sangue do lagarto Trachidosaurus rugosus rugosus (HACKETT E HANN, 1967) e das serpentes $B$. jararaca (NAHAS et al., 1973; NAHAS et al., 1981; TANAKA-AZEVEDO $e t$ al., 2003), B. jararacussu, B. alternatus e Crotalus durissus terrificus (DE MORAIS et al., 2008). Os anticoagulantes naturais parecem estar amplamente distribuídos entre as ordens de répteis (JACQUeS, 1963; Denson, 1976; Arocha-PiÑAngO, 1982). HACKetT E HANn (1967) sugeriram que a lentidão da coagulação dos répteis é devida, principalmente, à antitrombina circulante, sendo que essa antitrombina não é, comparativamente, mais potente que a de mamíferos, mas sua atividade se torna mais evidente pela deficiência da via intrínseca, que faz com que a conversão da protrombina em trombina seja mais lenta, tornando o efeito antitrombina mais proeminente.

Alguns estudos a respeito da hemostasia em $B$. jararaca indicam a presença de cininogênio (CHUDZINSKI, 1989), cininase e inibidores de cininogenases (LAVRAS, 1979) no 
plasma desses animais. No entanto, as atividades dos fatores XII, XI e precalicreína não foram observadas e os fatores VIII e IX apresentaram-se em baixas concentrações, mostrando que a ativação do sistema intrínseco pode ser diferente ou deficiente. Contudo, no plasma da serpente não peçonhenta Waglerophis merremii observou-se a atividade do fator XII, demonstrando que existe a ativação do sistema intrínseco, embora mais lenta quando comparada à humana (NAHAS et al., 1981).

De fato, as serpentes peçonhentas apresentam a via intrínseca mais lenta quando comparada a das serpentes não peçonhentas, o que pode sugerir que a presença de um inibidor de enzimas da coagulação pode desempenhar algum papel na proteção do animal contra seu próprio veneno (TANAKA-AZEVEDO et al., 2004).

TANAKA-AZEVEDO et al. (2003) descreveram um inibidor no plasma da serpente $B$. jararaca, chamado BjI, que interfere na atividade coagulante da trombina, medido pelo tempo de trombina, que, no entanto, não bloqueia a ativação da via extrínseca da coagulação, permitindo assim a oclusão de vasos lesados. Esse inibidor, entretanto, não interfere na atividade amidolítica da trombina nem na sua capacidade de estimular a agregação plaquetária. Provavelmente, este inibidor colabore com a existência das diferenças hemostáticas entre os mamíferos e as serpentes B. jararaca, principalmente em relação à lentidão da via intrínseca de coagulação sanguínea nesses animais. Além disso, os autores propuseram um possível papel desse inibidor na proteção desse animal contra seu próprio veneno.

Além de inibidores de enzimas da coagulação, o plasma da serpente $B$. jararaca também apresenta inibidores de outras proteases. Diversos investigadores relataram resistência em 
algumas espécies de serpentes aos efeitos tóxicos de seu veneno e ao veneno de outras espécies. Como exemplo, podemos citar uma proteína já isolada do plasma da serpente B. jararaca com atividade antiveneno, que inibe diferentes proteases responsáveis pela atividade coagulante e de ativação de protrombina presentes no veneno dessa serpente através da formação de complexo não covalente (TANIZAKI et al., 1991; OLIVEIRA E TANIZAKI, 1992). Essa resistência ao veneno poderia estar relacionada a um retardamento na formação de coágulos sanguíneos (ROSENFELD E GLASS, 1940).

Desta forma, o plasma da serpente B. jararaca apresenta-se como fonte rica de material, não somente para estudo do mecanismo da hemostasia dos répteis e comparada, bem como para o entendimento da relação entre o sangue e o veneno desses animais. 


\section{Objetivos}

O estudo da purificação e caracterização da antitrombina a partir do plasma da serpente $B$. jararaca é importante não apenas para a elucidação do mecanismo de ação desta enzima essencial para a fisiologia deste animal, mas também para a contribuição científica no estudo comparativo de proteínas humanas e de outras classes de animais, neste caso, réptil.

Assim, para entender melhor o sistema fisiológico das serpentes $B$. jararaca, os objetivos deste estudo foram:

1) Isolar e caracterizar a antitrombina presente no sangue dessa serpente;

2) Comparar esta proteína com a antitrombina de outros vertebrados. 


\section{Materiais e Métodos}

\subsection{Materiais}

\subsubsection{Animais}

\subsubsection{Serpentes}

Foram utilizadas 8 serpentes B. jararaca adultas fornecidas pelo Laboratório de Herpetologia do Instituto Butantan. Este projeto foi aprovado pela Comissão de Ética no Uso de Animais do Instituto Butantan (CEUAIB), protocolo número 156/04.

\subsubsection{Camundongos}

Foram utilizados cinco camundongos fornecidos pelo Biotério Central do Instituto Butantan, linhagem Balb/C, machos, adultos, com peso entre 18 e 20 gramas, para a produção de anticorpos policlonais anti-antitrombina de B. jararaca. Este projeto foi aprovado pela Comissão de Ética no Uso de Animais do Instituto Butantan (CEUAIB), protocolo número 425/07.

\subsubsection{Plasmas de outros animais vertebrados}

Amostras de plasma de peixe (Salminus hilarii) foram obtidas no Laboratório de Metabolismo e Reprodução de Peixes do Instituto de Biociências da Universidade de São Paulo. O plasma de rã (Rana catesbeiana) foi obtido através da sangria por punção cardíaca de um espécime cedido pelo Laboratório de Farmacologia do Instituto Butantan. O plasma da serpente não-peçonhenta Oxyrhopus guibei foi cedido pela Dra. Ida Sigueko Sano Martins, do Laboratório de Fisiopatologia do Instituto Butantan. O plasma de galinha (Gallus gallus) foi fornecido pelo Laboratório de Ornitologia da Faculdade de Medicina Veterinária e Zootecnia da Universidade 
de São Paulo. O plasma de coelho (Oryctogalus cuniculus) foi cedido pela Dra. Kátia Cristina Barbaro, do Laboratório de Imunopatologia do Instituto do Butantan e o plasma humano foi fornecido pelo Dr. Marcelo Larami Santoro, do Laboratório de Fisiopatologia do Instituto Butantan.

\subsubsection{Resina cromatográfica}

Foi utilizada a coluna cromatográfica HiTrap Heparin HP (1 mL) (GE Healthcare). Todas as cromatografias foram realizadas em aparelho ÄKTA Prime (Amersham Biosciences).

\subsection{Métodos}

\subsubsection{Coleta de sangue}

As serpentes B. jararaca foram anestesiadas com pentobarbital $(30 \mathrm{mg} / \mathrm{kg}$, via subcutânea) e submetidas a laparotomia. O sangue foi coletado pela artéria aorta abdominal e imediatamente colocado em presença do anticoagulante citrato de sódio a 3,8\% (p/v), na proporção de 9 partes de sangue e 1 parte de anticoagulante. O plasma foi obtido por centrifugação a $1200 \mathrm{~g}$ por 15 minutos a temperatura ambiente, sendo então armazenado a $-70^{\circ} \mathrm{C}$.

\subsubsection{Isolamento da antitrombina do plasma da serpente $B$. jararaca}

3.2.2.1. Purificação da antitrombina do plasma da serpente $B$. jararaca

O plasma de B. jararaca $(7 \mathrm{~mL})$ foi diluído em tampão Tris $100 \mathrm{mM}$, citrato de sódio 10 mM, NaCl 250 mM, pH 7,4 (3,5 mL) e aplicado em coluna HiTrap Heparin HP, previamente equilibrada com tampão Tris 100 mM, citrato de sódio 10 mM, NaCl 500 mM, pH 7,4 em fluxo de $1 \mathrm{~mL} / \mathrm{min}$. Em seguida, a coluna foi lavada com o mesmo tampão até chegar a resultados de 
leitura de $\mathrm{A}_{280}$ próximos do 0 . A antitrombina foi então eluída através de um gradiente descontínuo de sal, utilizando-se o mesmo tampão com $2 \mathrm{M}$ de $\mathrm{NaCl}$. Foram coletadas frações de $1 \mathrm{~mL}$. A dessalinização das amostras foi feita por diálise em água destilada durante 15 horas a $4^{\circ} \mathrm{C}$

\subsubsection{Dosagem das proteínas}

\subsection{Dosagem de proteínas por $\mathrm{A}_{280}$}

Durante o processo de purificação da antitrombina as proteínas de todas as frações foram quantificadas diretamente por $\mathrm{A}_{280}$ (STOSCHECK, 1990) em leitor de placas Spectramax 190 (Molecular Devices).

\subsection{Dosagem de proteínas utilizando-se ácido bicinconínico}

A concentração protéica das frações de interesse foi quantificada utilizando-se ácido bicinconínico (SMITH et al., 1985). Em uma placa de microtitulação, $10 \mu \mathrm{L}$ de amostra foram incubados com $200 \mu \mathrm{L}$ de mistura reativa, composta por 1 volume de solução de $\mathrm{CuSO}_{4} 4 \%$ (Sigma) para 50 volumes de solução de ácido bicinconínico (Sigma), por 25 segundos em microondas, em potência máxima. A leitura foi feita a $570 \mathrm{~nm}$ em leitor de placas Spectramax 190. O cálculo da dosagem de antitrombina foi feito através de uma curva-padrão, utilizando-se plasma de soroalbumina bovina (Sigma) como padrão.

\subsubsection{Dosagem da antitrombina}

A dosagem da antitrombina foi feita de acordo com o método colorimétrico descrito pelo fabricante do substrato cromogênico S-2238 (H-D-Phe-Pip-Arg-pNA) (Chromogenix). Assim, 
incubou-se $100 \mu \mathrm{L}$ da amostra diluída 1:50 em tampão tris-heparina (Tris $50 \mathrm{mM}, \mathrm{NaCl} 175 \mathrm{mM}$, EDTA 7,5 mM, heparina $3 \mathrm{U}, \mathrm{pH} 8,4$ ) por 5 minutos a $37^{\circ} \mathrm{C}$ e, em seguida, adicionou-se $25 \mu \mathrm{L}$ de trombina bovina $(2 \mathrm{U} / \mathrm{mL})$ (Sigma), incubando-se novamente a $37^{\circ} \mathrm{C}$ por 30 segundos. Adicionou-se então $15 \mu \mathrm{L}$ de substrato cromogênico S-2238 (4 mM) e após 5 minutos a $37^{\circ} \mathrm{C}$, a leitura foi feita a $405 \mathrm{~nm}$ em leitor de placas Spectramax 190. O cálculo da dosagem de antitrombina foi feito através de uma curva-padrão, utilizando-se plasma de B. jararaca como padrão.

\subsubsection{Métodos utilizados na caracterização da antitrombina da serpente $B$.}

jararaca

\subsubsection{Avaliação da atividade da antitrombina}

A atividade inibitória da antitrombina sobre a trombina na presença de heparina foi verificada segundo ABILDGAARD et al. modificado (1967). Em um tubo plástico foram adicionados $50 \mu \mathrm{L}$ de trombina bovina (5U/mL) (Sigma), $50 \mu \mathrm{L}$ de heparina (1U/mL) (Cristália) e $50 \mu \mathrm{L}$ de amostra $(0,1 \mathrm{mg} / \mathrm{mL})$. Esses reagentes foram incubados por 3 min a $37^{\circ} \mathrm{C}$. Em seguida, $100 \mu \mathrm{L}$ dessa mistura foram adicionados a um tubo de vidro contendo $100 \mu \mathrm{L}$ de fibrinogênio bovino ou de $B$. jararaca na concentração de $1 \mathrm{mg} / \mathrm{mL}$ e o tempo de coagulação foi cronometrado. $\mathrm{O}$ mesmo teste foi realizado na ausência de heparina e/ou antitrombina.

\subsubsection{Eletroforese em gel de poliacrilamida contendo SDS (SDS-PAGE)}

A purificação da antitrombina foi acompanhada por eletroforese em gel de poliacrilamida a 10\% e gradiente de 5 a 12\%, segundo LAEMMLI (1970), utilizando-se $1 \mu \mathrm{g}$ de proteína por canaleta. 
O gel de poliacrilamida foi preparado utilizando-se quantidades adequadas de soluções estoque de acrilamida 30\% (p/v) (Gibco BRL) e bis-acrilamida 0,8\% (Gibco BRL). Além destas soluções, a mistura para o preparo do gel continha também: tampão Tris- $\mathrm{HCl} 375 \mathrm{mM}, \mathrm{pH} 8,8$, SDS 0,1\% (USB Corporation), TEMED 0,05\% (Merck) e persulfato de amônio 0,05\% (p/v) (Gibco BRL). Os dois últimos reagentes foram acrescentados e, imediatamente, a solução foi cuidadosamente amoldada entre duas placas de vidro.

Para a formação do gel de empilhamento, adicionou-se a mistura do gel de poliacrilamida, como descrito acima, em concentração final de 3\%, e foi encaixado entre as placas de vidro um espaçador na forma de um pente de $1 \mathrm{~mm}$ de espessura, com 10 canaletas.

Paralelamente à polimerização do gel, foi adicionado às amostras tampão de amostra (TrisHCl 50 mM, SDS 1\%, glicerol 10\%, azul de bromofenol 0,004\%, pH 6,8). Para atingir condições redutoras, o tampão de amostra foi acrescido de $\beta$-mercaptoetanol 0,5\%. As amostras foram então fervidas em banho seco a $100^{\circ} \mathrm{C}$ por sete minutos e, em seguida, centrifugadas rapidamente.

O tampão de corrida utilizado foi tris-glicina (Tris $25 \mathrm{mM}$, glicina $192 \mathrm{mM}$, SDS 1\%, pH 8,3). As amostras foram aplicadas e a corrida foi realizada em sistema Mini Protean II (BioRad) em amperagem constante de $30 \mathrm{~mA}$ (fonte BioRad modelo PowerPac 1000) até que a banda do corante presente no tampão de amostra atingisse a extremidade inferior do gel. 


\subsubsection{Focalização isoelétrica (IEF)}

A focalização isoelétrica da antitrombina foi realizada utilizando-se PhastGel IEF 3-9 (GE Healthcare) em sistema PhastSystem (GE Healthcare), segundo recomendações do fabricante. Utilizando-se PhastGel Samples Applicators (GE Healthcare) foram aplicados $300 \mathrm{ng}$ de antitrombina purificada de B. jararaca.

\subsubsection{Coloração do gel de poliacrilamida e do gel de focalização isoelétrica}

Os géis de poliacrilamida e de focalização isoelétrica foram corados utilizando-se solução de nitrato de prata, de acordo com BLUM (1987).

Após a eletroforese e a focalização isoelétrica, as proteínas presentes no gel de poliacrilamida foram fixadas por uma hora em solução contendo metanol $50 \%$, ácido acético $12 \%$ e formaldeído $37 \%$ 0,5 mL/L. Em seguida, o gel foi lavado em etanol $50 \%$ por uma hora, sendo efetuadas três trocas durante este intervalo de tempo. Foi realizado então o tratamento prévio do gel por 1 minuto utilizando-se solução de tiossulfato de sódio 50\% (0,2 g/L), sendo realizadas duas trocas durante este intervalo de tempo. A seguir, o gel foi lavado com água destilada (três vezes de 20 segundos) e colocado em solução contendo nitrato de prata $20 \% 2 \mathrm{~g} / \mathrm{L}$ e formaldeído $37 \%$ 0,75 mL/L, permanecendo nesta solução por 20 minutos. Em seguida, o gel foi lavado novamente com água destilada (duas vezes de 20 segundos) e revelado em solução contendo carbonato de sódio $20 \%$, formaldeído $37 \%$ 0,75 mL/L e tiossulfato de sódio $50 \%$ 0,2 g/L. Após o aparecimento das bandas, a reação foi interrompida utilizando-se solução contendo metanol 50\% e ácido acético 12\%. O gel foi então colocado entre duas folhas de papel celofane e seco a temperatura ambiente. 


\subsubsection{Coloração do gel de poliacrilamida para identificação de}

glicoproteínas

O teste de Schiff (FAIRBANKS et al., 1971) foi utilizado para verificar a presença de açúcares na molécula de antitrombina. Para este ensaio, foram utilizados $4 \mu \mathrm{g}$ de proteína.

Após a eletroforese, as proteínas presentes no gel de poliacrilamida foram fixadas por 15 horas em solução contendo ácido acético $25 \%$ e álcool isopropílico 10\%. Em seguida, o gel foi lavado em ácido periódico $0,5 \%$ por duas horas, no escuro. O gel foi então lavado com ácido acético $10 \%$ por 2 horas, no escuro. A seguir, o gel foi corado com reativo de Schiff por 2 horas a $4^{\circ} \mathrm{C}$ e revelado por 15 horas em solução contendo metabissulfito de sódio $0,1 \%$ e ácido clorídrico $10 \mathrm{mM}$. Finalmente, o gel foi colocado entre duas folhas de papel celofane e seco a temperatura ambiente.

\subsubsection{Deglicosilação da antitrombina}

A antitrombina de B. jararaca $(14 \mu \mathrm{g})$ foi deglicosilada utilizando-se ácido trifluorometanossulfônico (TFMS) segundo EDGE (1981).

Em banho de gelo, foram adicionados $500 \mu \mathrm{L}$ de anisol (Fluka) e $1 \mathrm{~mL}$ de TFMS (Sigma) em um recipiente de vidro. $500 \mu \mathrm{L}$ desta solução foram transferidos para um tubo de ensaio contendo $25 \mu \mathrm{g}$ de antitrombina liofilizada de $B$. jararaca, a qual foi ressuspendida e transferida para um recipiente de vidro. A amostra foi então borbulhada em nitrogênio e o recipiente foi vedado e mantido sob agitação em banho de gelo por 2 horas e 30 minutos. Em seguida, foi 
adicionado $1 \mathrm{~mL}$ de éter etílico (Vetec) gelado. O mesmo volume de piridina (Baker) foi adicionado, ainda em banho de gelo. O precipitado foi ressupendido e o éter etílico foi removido. O mesmo volume de éter foi novamente adicionado, o precipitado foi ressuspendido e o éter mais uma vez foi removido. A amostra foi dialisada conta $500 \mathrm{~mL}$ de água destilada por 15 horas a $4^{\circ} \mathrm{C}$

\subsubsection{Desintometria}

A massa molecular da antitrombina, com e sem redução por $\beta$-mercaptoetanol, e após o precesso de deglicosilação (descrito no item 3.2.3.6) foi analisada por densitometria do gel de poliacrilamida (descrito no item 3.2.3.2) escaneado, utilizando o programa TotalLab.

\subsubsection{Sequienciamento da região amino-terminal da antitrombina de $B$.}

\section{jararaca por degradação de Edman}

A antitrombina isolada de $B$. jararaca $(3,45 \mu \mathrm{g})$ foi submetida à eletroforese em gel de poliacrilamida $10 \%$ em condições reduzidas (presença de $\beta$-mercaptoetanol), segundo item 3.2.3.2. Após a corrida, a proteína foi transferida para membrana de difluoreto de polivinidileno (PVDF) (Sigma-Aldrich Chemical Co) previamente equilibrada inicialmente em metanol e em seguida em tampão de transferência (Tris-base 25 mM, glicina 192 mM, etanol 20\%) em sistema BioRad (modelo PowerPac 1000) por 2 horas com voltagem constante (20 V). Em seguida, a membrana foi lavada com água destilada e imediatamente seca em estufa a $37^{\circ}$. Após 30 minutos, a membrana foi corada com coomassie blue $0,1 \%$ em $50 \%$ de metanol por 10 minutos e depois descorada com metanol $50 \%$ e ácido acético 10\%. Em seguida, a membrana foi lavada sucessivas vezes com água destilada e a banda correspondente a antitrombina foi excisada e 
seqüenciada. A cadeia foi seqüenciada utilizando-se seqüenciador automático modelo PPSQ-23 (Schimatzu). As seqüências já descritas para outros animais foram obtidas através do site www.ncbi.nlm.nih.gov e comparadas com a de B. jararaca através do programa Clustal X.

\subsubsection{Espectrometria de massa (MALDI-TOF)}

A antitrombina isolada de B. jararaca $(4 \mu \mathrm{g})$ foi submetida a eletroforese em gel de poliacrilamida $10 \%$ em condições reduzidas (presença de $\beta$-mercaptoetanol), segundo item 3.2.3.2. Após a corrida, a banda referente à antitrombina foi excisada do gel, colocada em placa de MALDI (Millipore) e processada conforme as recomendações do fabricante.

Brevemente, a banda protéica excisada do gel de poliacrilamida foi lavada em solução de bicarbonato de amônio $25 \mathrm{mM}$ e acetonitrila $5 \%$ por 30 minutos e descorada com solução de bicarbonato de amônio $100 \mathrm{mM}$ e acetonitrila $50 \%$ por 30 minutos, sendo este último processo realizado mais uma vez. O gel de poliacrilamida contendo a proteína de interesse foi desidratado com acetonitrila $100 \%$ por 15 minutos, re-hidratado em $15 \mu$ de bicarbonato de amônio $25 \mathrm{mM}$ contendo $100 \mathrm{ng}$ de tripsina (Trypsin Gold - Promega), e incubado a $35^{\circ} \mathrm{C}$ por 15 horas.

A resina $\mathrm{C}_{18}$ presente no ZipPlate foi ativada com $9 \mu \mathrm{l}$ de acetonitrila por 15 minutos a $37^{\circ} \mathrm{C}$. Os peptídeos foram removidos do gel de poliacrilamida com $180 \mu \mathrm{l}$ de ácido trifluoroacético 0,1\% (TFA) por 30 minutos e então ligados à resina através de vácuo fraco. Em seguida foram lavados duas vezes com $100 \mu \mathrm{l}$ de TFA em vácuo forte. Os peptídeos foram eluídos diretamente em placa de MALDI (PerkinElmer) com matriz de ácido $\alpha$-ciano-4-hidroxi 
cinamico (LaserBiolabs, Sophid-Antipolis Cedex, France) ( $\alpha$-CHCA a $10 \mathrm{mg} / \mathrm{mL}$ ) em solução de acetonitrila 50\% e TFA $50 \%$.

Permitiu-se que a matriz secasse a temperatura ambiente para a formação de cristais e em seguida a placa de MALDI foi colocada em espectrômetro de massa prO-TOF 2000 MALDITOF (PerkinElmer). O instrumento foi calibrado através do método de dois pontos de calibração utilizando-se uma mistura de calibração para peptídeos (LaserBiolabs). Foram avaliados os peptídeos com massa molecular entre 750-4500 Da. Os peptídeos foram identificados através do site www.ncbi.nlm.nih.gov utilizando-se o programa ProFound. A comparação entre as seqüência peptídicas obtidas e as seqüências das antitrombinas previamente descritas foi realizada através do site www.ncbi.nlm.nih.gov utilizando-se o programa ClustalW.

\subsubsection{Produção de anticorpos policlonais anti-antitrombina de B. jararaca} em camundongos

A imunização foi realizada em camundongos machos Balb C, utilizando-se a antitrombina de B. jararaca purificada como imunógeno.

Os camundongos receberam, via subcutânea, uma dose da antitrombina purificada (10 $\mu \mathrm{g}$ /camundongo), utilizando-se $500 \mu \mathrm{L}$ de Marcol-Montanide como adjuvante, na proporção de 9 volumes de Marcol 52 (Esso Standard Oil Co) para 1 volume de Montanide 888 (SEPPIC). Foram realizados três reforços de imunização, após 21, 36 e 60 dias, sendo que os camundongos receberam, sob as mesmas condições, uma quantidade idêntica de proteína purificada. Em cada reforço, também foi realizada uma sangria via plexo ocular de cada animal. Após 70 dias, os 
camundongos foram anestesiados com solução composta por xilazina (Rumpum®) e cloridrato de quetamina (Ketalar $\left.{ }^{\circledR}\right)$ em uma proporção de $1: 1$, por via intraperitonial $(50 \mu \mathrm{L} / 20 \mathrm{~g}$ de peso do animal), e todo o sangue dos animais foi coletado por punção cardíaca para a obtenção de anticorpos.

O soro foi separado através da incubação do sangue a $37^{\circ} \mathrm{C}$ por 1 hora para a formação do coágulo e centrifugação por 10 minutos a $1200 \mathrm{~g}$. O soro anti-antitrombina de B. jararaca foi mantido a $-70^{\circ} \mathrm{C}$ até a sua utilização.

3.2.3.11. Determinação do título de anticorpos anti-antitrombina de B. jararaca pelo método imunoenzimático (ELISA)

O título dos anticorpos anti-antitrombina produzidos segundo o item 3.2.3.10 foi determinado utilizando-se o método de ELISA (HARLOW E LANE, 1988).

Placas de microtitulação de poliestireno foram sensibilizadas com $100 \mu \mathrm{L}$ de antitrombina (10 $\mu \mathrm{g} / \mathrm{mL}$ ) diluída em tampão carbonato/bicarbonato de sódio $50 \mathrm{mM}, \mathrm{pH}$ 9,6, por 15 horas a $4^{\circ} \mathrm{C}$, em câmara úmida. Estas foram, então, submetidas a três lavagens sucessivas, sendo cada lavagem de 5 minutos, com tampão fosfato de sódio 10 mM, NaCl 150 mM, pH 7,4 (PBS) contendo tween 20 0,05\%. Em seguida, foram adicionados $200 \mu \mathrm{L}$ da solução bloqueadora (leite Molico 5\%), mantendo-se a $37^{\circ} \mathrm{C}$ por 1 hora. Após um novo ciclo de lavagens, foram adicionados $100 \mu \mathrm{L}$ dos soros anti-antitrombina em cada poço, obtidos segundo o item 3.2.3.10, em diluições seriadas com tampão de incubação (PBS, pH 7,4, contendo Molico 1\%) e deixou-se novamente a $37^{\circ} \mathrm{C}$ por duas horas. Após outro ciclo de lavagens, as placas foram incubadas a 
$37^{\circ} \mathrm{C}$ por 1 hora com $100 \mu \mathrm{L}$ por poço do conjugado imunoenzimático (anti-IgG de camundongo conjugada com peroxidase) (Sigma) diluído 1:10.000 com tampão de incubação. Após mais um ciclo de lavagens, a reação foi revelada pela adição de $100 \mu \mathrm{L}$ da mistura cromógena e substrato da enzima (1 mg de orto-fenilenodiamino/mL em tampão citrato de sódio $0,2 \mathrm{M}$ pH 5,0, contendo 0,01\% de $\mathrm{H}_{2} \mathrm{O}_{2}$ ). Após 5 minutos de incubação a temperatura ambiente, a reação foi interrompida pela adição de $50 \mu \mathrm{L}$ de $\mathrm{H}_{2} \mathrm{SO}_{4} 30 \%$. A reação foi acompanhada pela leitura de $\mathrm{A}_{492} \mathrm{~nm}$ em espectrofotômetro de placas Spectramax 190. O título de anticorpos foi determinado pela recíproca da diluição máxima de soro capaz de resultar em uma leitura próxima de 0,100, multiplicada pelo valor da leitura.

\subsubsection{2. "Western blotting"}

O método "Western blotting" foi utilizado para verificar a ocorrência de reação imunológica cruzada entre a antitrombina isolada de $B$. jararaca e a antitrombina de outros animais vertebrados (peixe, rã, serpente não-peçonhenta, galinha, coelho e homem).

As proteínas presentes no plasma desses animais e a antitrombina isolada de B. jararaca, após eletroforese em gel de poliacrilamida $10 \%$ utilizando-se $12 \mu \mathrm{g}$ de proteína, foram transferidas para uma membrana de nitrocelulose (Sigma-Aldrich Chemical Co) previamente equilibrada em tampão de transferência (Tris-base 25 mM, glicina 192 mM, etanol 20\%) em sistema BioRad (modelo PowerPac 1000) por 2 horas com voltagem constante (20 V). Após a transferência, a membrana foi corada com Ponceau S para verificar a eficiência da transferência (Ponceau 0,5\% e ácido acético 1\%) e, em seguida, descorada com água destilada. Em seguida, a membrana foi bloqueada com solução bloqueadora (leite Molico 5\%) contendo tween 20 0,01\% 
por 15 horas a $4{ }^{\circ} \mathrm{C}$. Esta foi, então, submetida a 3 lavagens sucessivas, sendo cada lavagem de 5 minutos, com solução de lavagem (Tris $10 \mathrm{mM}, \mathrm{NaCl} 150 \mathrm{mM}$, twen 20 0,01\%, pH 7,5). Em seguida, a membrana foi incubada com o anticorpo anti-antitrombina obtido segundo o item 3.2.3.10 diluído 1:1.000 em solução de incubação (gelatina de peixe $0,5 \%$, contendo tween 20 $0,01 \%$ ), por 2 horas a temperatura ambiente. Após um novo ciclo de lavagens, a membrana foi incubada com o conjugado imunoenzimático (anti-IgG de camundongo conjugada com peroxidase) (Sigma) diluído 1:10.000 em tampão de incubação por 2 horas a temperatura ambiente. Após mais um ciclo de lavagens, a reação foi revelada adicionando-se substrato cromogênico (5 mg de 3,3'diaminobenzidina (tetrahidrocloreto) (Sigma), $10 \mathrm{~mL}$ de tampão imidazol 0,1 M, $125 \mu \mathrm{L}$ de $\mathrm{CoCl}_{2}$ 0,2 $\mathrm{M}$ e $3,4 \mu \mathrm{L} \mathrm{H}_{2} \mathrm{O}_{2} 30 \%$ ). A reação foi interrompida pela adição de água destilada. 


\section{Resultados}

\subsection{Isolamento da antitrombina do plasma da serpente $B$. jararaca}

As etapas de purificação da antitrombina de B. jararaca compreenderam coleta de sangue, obtenção do plasma e cromatografia de afinidade (HiTrap Heparin HP) (figura 8).

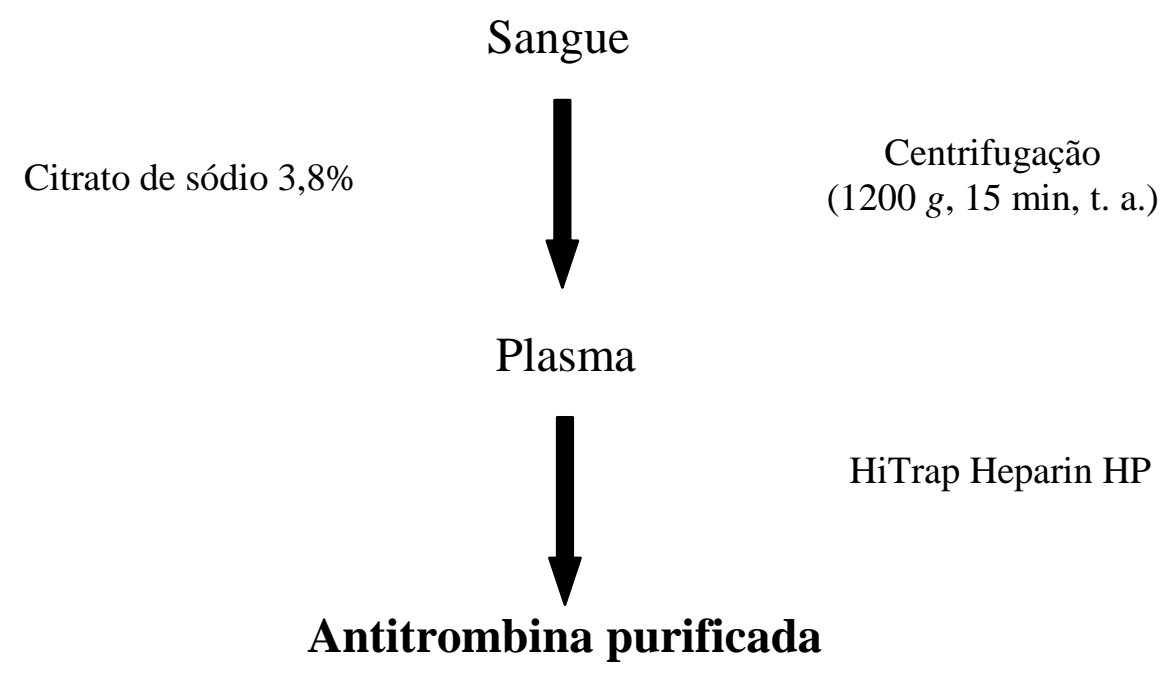

Figura 8. Fluxograma do processo de purificação da antitrombina do plasma da serepente B. jararaca.

O plasma de B. jararaca foi inicialmente diluído em tampão Tris 100 mM, citrato de sódio $10 \mathrm{mM}, \mathrm{NaCl} 250 \mathrm{mM}, \mathrm{pH} 7,4$ e submetido à cromatografia de afinidade em coluna HiTrap Heparin HP. A figura 9 mostra o perfil deste passo de purificação. 


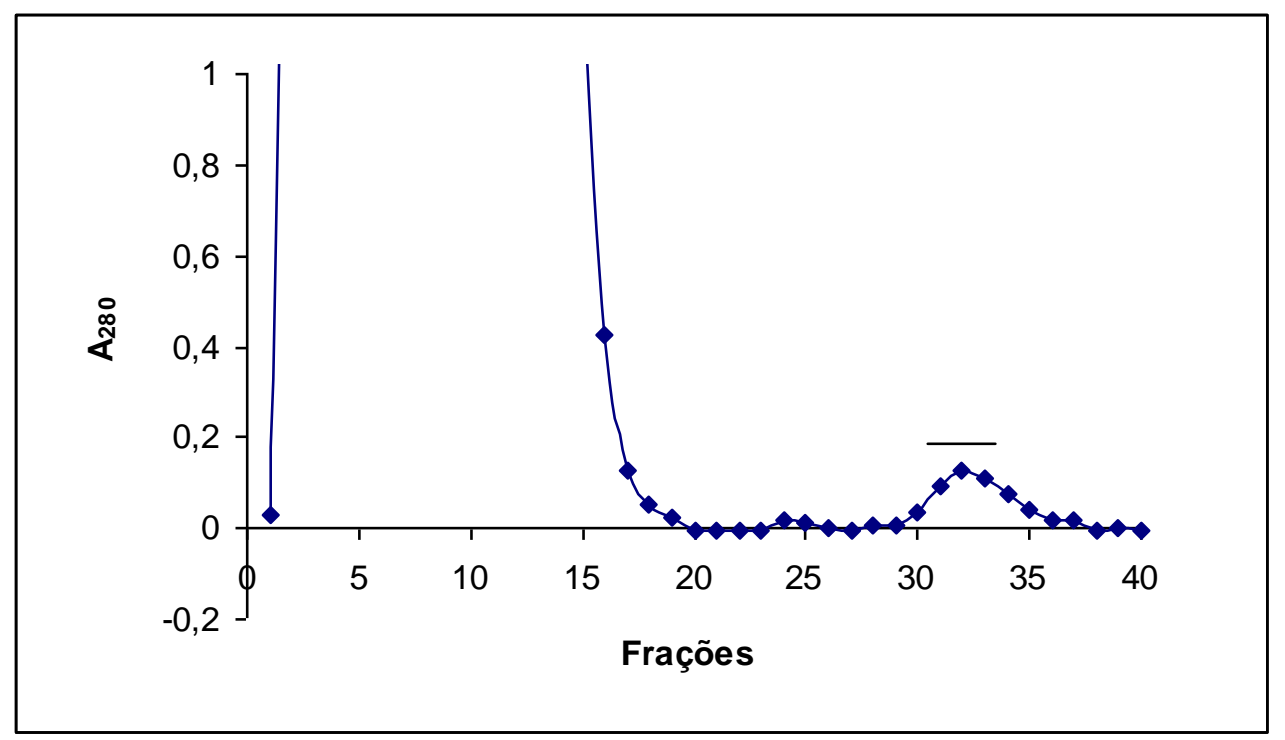

Figura 9. Cromatografia de afinidade do processo de purificação da antitrombina do plasma de $B$. jararaca em coluna HiTrap Heparin HP. O plasma de B. jararaca $(7 \mathrm{~mL})$ foi diluído em tampão Tris 100 $\mathrm{mM}$, citrato de sódio $10 \mathrm{mM}, \mathrm{NaCl} 250 \mathrm{mM}, \mathrm{pH}$ 7,4 e aplicado em coluna HiTrap Heparin HP previamente equilibrada com tampão Tris $100 \mathrm{mM}$, citrato de sódio $10 \mathrm{mM}, \mathrm{NaCl} 500 \mathrm{mM}, \mathrm{pH}$ 7,4 em fluxo de $1 \mathrm{~mL} / \mathrm{min}$. A eluição foi feita através do gradiente descontínuo utilizando o mesmo tampão de equilíbrio, contendo $2 \mathrm{M}$ de $\mathrm{NaCl}$. A cromatografia foi acompanhada por $\mathrm{A}_{280}$. Frações 31-33 (-): frações com atividade inibitória sobre a trombina bovina.

\subsubsection{Dosagem da antitrombina}

A dosagem da antitrombina foi feita através de ensaio colorimétrico, utilizando-se substrato cromogênico S-2238, conforme as recomendações do fabricante. O cálculo da dosagem de antitrombina foi feito através de uma curva-padrão, utilizando-se diferentes diluições de plasma de B. jararaca como padrão (tabela 1 e figura 10). 
Tabela 1. Curva-padrão da antitrombina em diferentes diluições do plasma da serpente B. jararaca.

\begin{tabular}{cc}
\hline Antitrombina (\%) & $\mathbf{A}_{\mathbf{4 0 5}}{ }^{*}$ \\
\hline 0 & 1,0189 \\
25 & 0,9138 \\
50 & 0,5642 \\
75 & 0,4366 \\
100 & 0,2523 \\
\hline
\end{tabular}

* Avaliada através de ensaio colorimétrico de acordo com as recomendações do fabricante do substrato cromogênico S-2238.

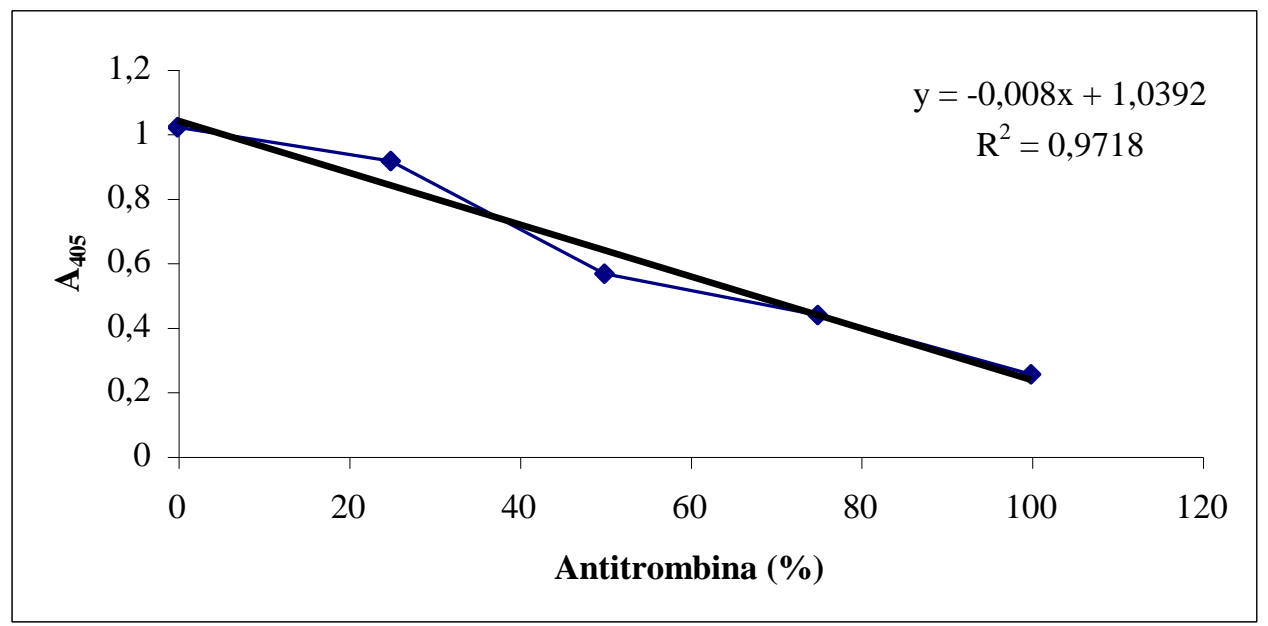

Figura 10. Curva-padrão para dosagem da antitrombina do plasma da serpente B. jararaca.

Após o teste da atividade inibitória sobre a trombina bovina utilizando-se o substrato cromogênico S-2238 foi verificado que a antitrombina estava presente nas frações 31-33, eluídas com $2 \mathrm{M}$ de $\mathrm{NaCl}$. Estas foram então reunidas, dialisadas contra água destilada e aliquotadas. 
Observa-se na tabela 2 que o processo de purificação utilizado apresentou uma recuperação da atividade de cerca de $24 \%$. A antitrombina foi purificada 87 vezes, aproximadamente, e apresentou uma atividade específica final de 500,68 (U/mg).

Tabela 2. Processo de purificação da antitrombina do plasma da serpente $B$. jararaca.

\begin{tabular}{|c|c|c|c|c|c|c|c|c|c|}
\hline Amostra & $\begin{array}{c}\text { Volume } \\
(\mathrm{mL})\end{array}$ & $\begin{array}{l}\text { Proteína } \\
(\mathrm{mg} / \mathrm{mL})^{*}\end{array}$ & $\begin{array}{c}\text { Proteína total } \\
\text { (mg) }\end{array}$ & $\mathbf{A}_{405}{ }^{* *}$ & $\mathrm{AT}^{* * *} \% / \mathrm{mL}$ & AT\% total & $\begin{array}{c}\text { Recuperação } \\
(\%)\end{array}$ & $\operatorname{Aesp}^{* * * *} / \mathrm{mg}$ & Purificação \\
\hline Plasma & 7 & 17,09 & 119,63 & 0,252 & 98,36 & 688,52 & 100,00 & 5,76 & 1,00 \\
\hline Frações 2-16 & 15 & 10,29 & 154,35 & 1,062 & 0,00 & 0,00 & 0,00 & 0 & 0,00 \\
\hline Frações 31-33 & 1,5 & 0,22 & 0,33 & 0,158 & 110,15 & 165,23 & 24,00 & 500,68 & 86,99 \\
\hline
\end{tabular}

*Valores obtidos através da dosagem de proteínas utilizando-se ácido bicinconínico.

*** Avaliada através de ensaio colorimétrico de acordo com as recomendações do fabricante do substrato cromogênico S-2238.

**** AT - antitrombina

${ }^{* * * *}$ Aesp - atividade específica

Utilizando-se os dados obtidos na tabela 2, a concentração de antitrombina no plasma de B. jararaca foi estimada em $188 \mu \mathrm{g} / \mathrm{mL}$ de plasma. 


\subsection{Caracterização bioquímica da antitrombina do plasma da serpente $B$.}

jararaca

\subsubsection{Avaliação da atividade da antitrombina}

A influência da antitrombina purificada de $B$. jararaca sobre o tempo de trombina está representada na tabela 3. O teste de coagulação utilizado para avaliar a atividade inibitória da antitrombina sobre a trombina, na presença e ausência de heparina, revelou que a atividade da antitrombina de B. jararaca é aumentada na presença deste polissacarídeo. Quando o teste foi realizado somente na presença de trombina e fibrinogênio, o tempo de trombina foi 11 e 35 segundos para fibrinogênio bovino e de $B$. jararaca, respectivamente, enquanto a presença de antitrombina ou heparina causou um discreto prolongamento no tempo de formação da fibrina. No entanto, a presença de antitrombina e heparina tornou ambos os fibrinogênios incoaguláveis (>600 segundos para fibrinogênio bovino e de B. jararaca).

Tabela 3. Atividade inibitória da antitrombina (AT) $(0,1 \mathrm{mg} / \mathrm{mL})$ sobre a trombina $(\mathrm{T})(5 \mathrm{U} / \mathrm{mL}) \mathrm{na}$ presença e na ausência de heparina (Hep) $(1 \mathrm{U} / \mathrm{mL})$. Este ensaio foi realizado com fibrinogênio (Fib) bovino e de B. jararaca (ambos na concentração de $1 \mathrm{mg} / \mathrm{mL}$ ).

Tempo de coagulação (s)

\begin{tabular}{ccc} 
& Fibrinogênio bovino & Fibrinogênio de B. jararaca \\
\hline T & 11 & 35 \\
T + AT & 16 & 49 \\
T + Hep & 17 & 43 \\
T + AT + Hep & $>600$ & $>600$ \\
\hline
\end{tabular}




\subsubsection{Eletroforese em gel de poliacrilamida contendo SDS (SDS-PAGE)}

A purificação da antitrombina foi acompanhada por eletroforese em gel de poliacrilamida a $10 \%$ e gradiente de 5 a $12 \%$, com e sem redução por $\beta$-mercaptoetanol.

Pode-se observar nas figuras 11 e 12 que após a cromatografia a antitrombina está livre de contaminantes, apresentando uma única banda tanto na ausência quanto na presença de $\beta$ mercaptoetanol, o que indica que esta proteína consiste em uma única cadeia polipeptídica com massa molecular de aproximadamente $61 \mathrm{kDa}$.

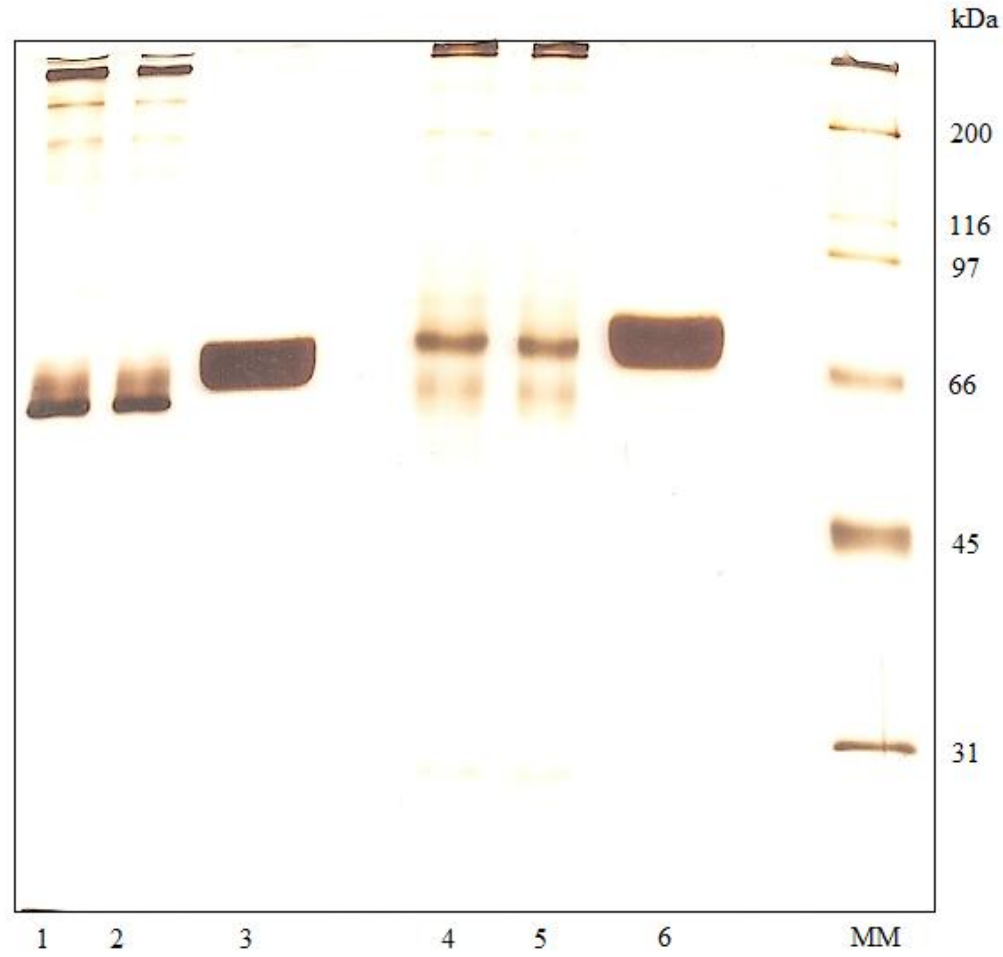

Figura 11. SDS-PAGE (10\%) da antitrombina do plasma da serpente $B$. jararaca em condições não reduzidas (1-3) e reduzidas (4-6). Canaletas (1 e 4) plasma de B. jararaca, (2 e 5) "flow through" (frações 2-16), (3 e 6) antitrombina purificada de B. jararaca e (7) marcador de massa molecular (MM) (Biorad) $(10 \mu \mathrm{L})$ do maior para o menor e com massa molecular de: miosina (200 kDa), $\beta$-galactosidade (116 
$\mathrm{kDa}$ ), fosforilase b (97 kDa), albumina (66 kDa), ovoalbumina (45 kDa), anidrase carbônica (31 kDa) e inibidor de tripsina $(21 \mathrm{kDa})$. As proteínas $(1 \mu \mathrm{g})$ foram coradas por nitrato de prata.

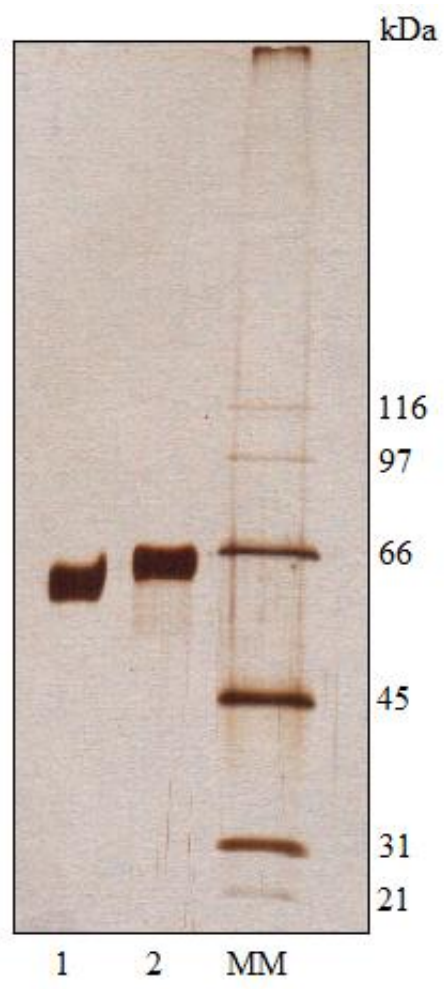

Figura 12. SDS-PAGE (gradiente de poliacrilamida de 5 a 12\%) da antitrombina do plasma da serpente B. jararaca em condições não reduzidas (canaleta 1) e reduzidas (canaleta 2). Canaleta (3) marcador de massa molecular (MM) (BioRad) $(10 \mu \mathrm{L})$ do maior para o menor e com massa molecular de: miosina (200 kDa), $\beta$-galactosidade (116 kDa), fosforilase b (97 kDa), albumina (66 kDa), ovoalbumina (45 kDa), anidrase carbônica $(31 \mathrm{kDa})$ e inibidor de tripsina $(21 \mathrm{kDa})$. As proteínas $(1 \mu \mathrm{g})$ foram coradas por nitrato de prata. 


\subsubsection{Focalização isoelétrica (IEF)}

A antitrombina purificada de $B$. jararaca foi submetida à focalização isoelétrica, em uma variação de pH de 3 a 9. Os resultados indicaram um ponto isoelétrico (pI) ácido, de 4,5 (figura 13).

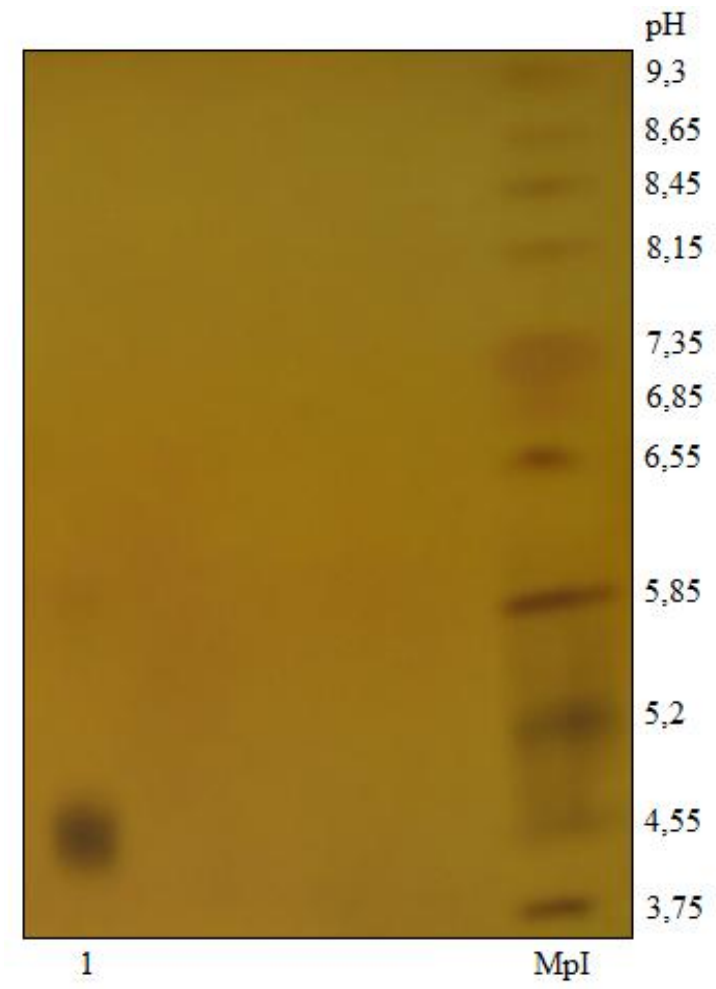

Figura 13. Focalização isoelétrica da antitrombina de $B$. jararaca. Canaleta (1) antitrombina de $B$. jararaca e (MpI) marcador de ponto isoelétrico (GE Healthcare) $(6 \mu \mathrm{L})$ na faixa de $\mathrm{pH}$ de 3 a 9, do maior para o menor e com pH igual a: tripsinogênio $(9,3)$, lecitina (básica) $(8,65)$, lecitina (intermediária) $(8,45)$, lecitina ácida (8,15), mioglobulina de cavalo (básica) (7,35), mioglobulina de cavalo (ácida) $(6,85)$, anidrase carbônica B humana $(6,55)$, anidrase carbônica B bovina $(5,85), \beta$-lactoblobulina A $(5,2)$, inibidor de tripsina de sementes de soja $(4,55)$ e vermelho de metila $(3,75)$. As proteínas $(300 \mathrm{ng})$ foram coradas com nitrato de prata. 


\subsubsection{Identificação de glicoproteínas}

A fim de verificar a presença de açúcares na molécula de antitrombina o gel de poliacrilamida foi corado utilizando-se o reativo de Schiff (FAIRBANKS et al., 1971). Esse teste revelou que a antitrombina isolada de B. jararaca é uma glicoproteína (figura 14).

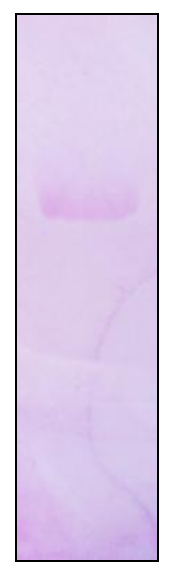

Figura 14. SDS-PAGE (10\%) da antitrombina do plasma da serpente B. jararaca em condições não reduzidas. As proteínas $(4 \mu \mathrm{g})$ foram coradas com reativo de Schiff.

\subsubsection{Deglicosilação}

A antitrombina de B. jararaca foi deglicosilada utilizando TFMS. Este processo resultou na mudança de peso molecular da proteína deglicosilada de 61 para $50 \mathrm{kDa}$, como pode ser observado na figura 15. O conteúdo total de carboidrato foi estimado em $18 \%$. 


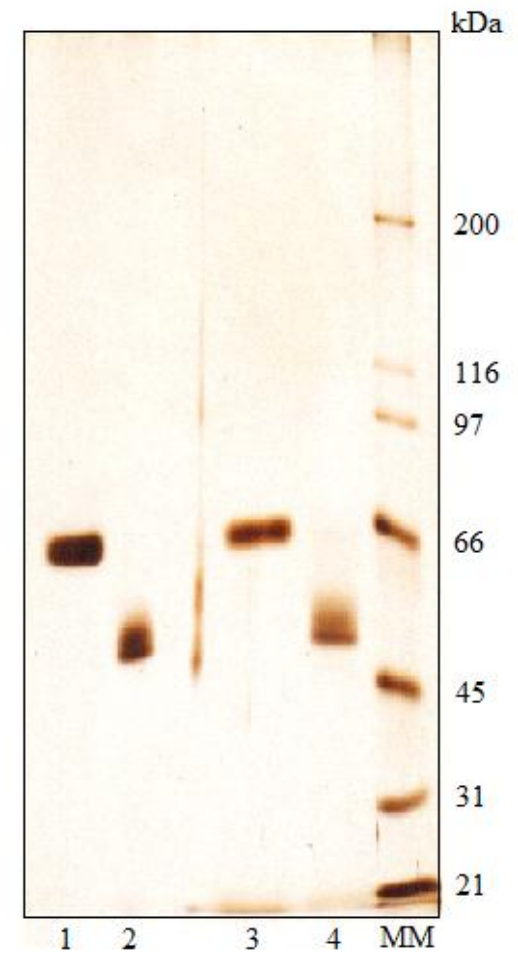

Figura 15. SDS-PAGE (gradiente de poliacrilamida de 5 a 12\%) da antitrombina de B. jararaca após deglicosilação com TFMS, sob condições não-reduzidas (canaletas 1 e 2) e reduzidas (canaletas 3 e 4). Canaletas (1) e (3) antitrombina de B. jararaca, (2) e (4) antitrombina de B. jararaca tratada com TFMS e (5) marcador de massa molecular $(\mathrm{MM})($ BioRad) $(10 \mu \mathrm{L})$, do maior para o menor e com massa molecular de: miosina (200 kDa), $\beta$-galactosidade (116 kDa), fosforilase b (97 kDa), albumina (66 kDa), ovoalbumina (45 kDa), anidrase carbônica $(31 \mathrm{kDa})$ e inibidor de tripsina $(21 \mathrm{kDa})$. As proteínas $(1 \mu \mathrm{g})$ foram coradas com nitrato de prata.

\subsubsection{Seqüenciamento da região amino-terminal da antitrombina de $B$. jararaca por degradação de Edman}

A análise dos aminoácidos da região amino-terminal da antitrombina de B. jararaca resultou na seguinte seqüência: His-Glu-Ser-Ser-Val-Gln-Asp-Ile-Ile-Thr. Quando esta seqüência 
foi comparada à seqüência da antitrombina de outras espécies (figura 16) observamos um resíduo em comum com a antitrombina de salmão (10\% de identidade), dois resíduos em comum com a antitrombina de zebrafish ( $20 \%$ de identidade), três resíduos em comum com a de rato, hamster e avestruz (30\% de identidade), quatro resíduos em comum com a de galinha (40\% de identidade), cindo resíduos em comum com a bovina e a humana (50\% de identidade), seis resíduos em comum com a eqüina e a suína (60\% de identidade) e sete resíduos em comum com a de coelho (70\% de identidade).

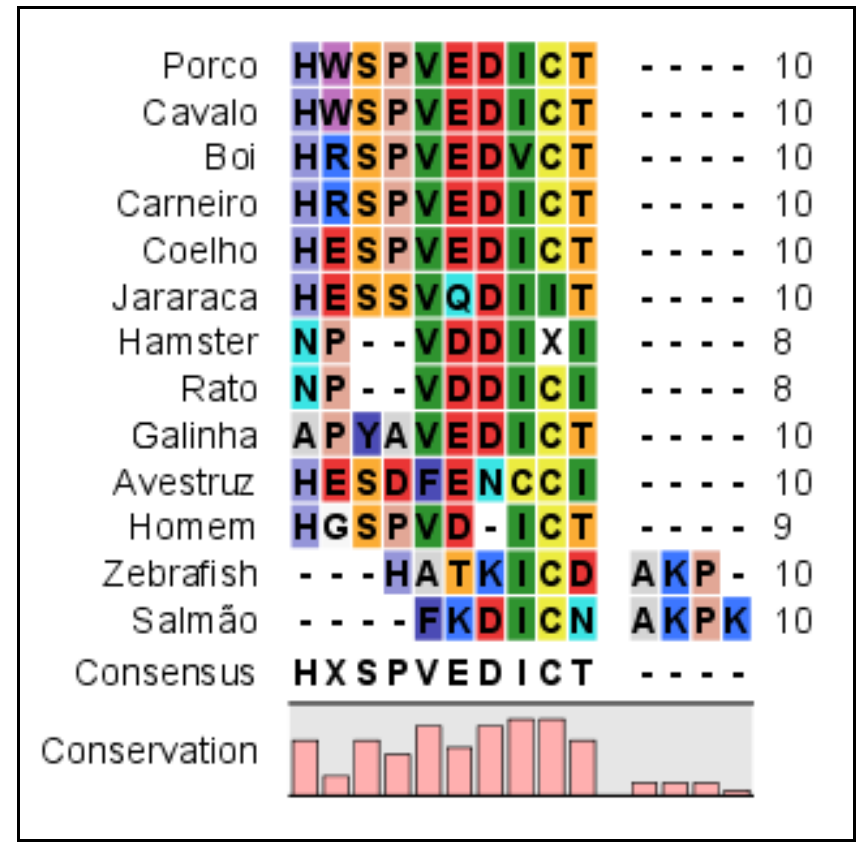

Figura 16. Seqüência amino-terminal da antitrombina de $B$. jararaca comparada à seqüência da antitrombina de outros animais. Referências: bovina (KOIDE, 1979), eqüina (THALER E SCHMER, 1975), de carneiro (OlSON E BJORK, 1994), de porco (KOIDE, 1979), de coelho (KOIDE, 1979), de hamster (MAK et al., 1996), de rato (KOIDE, 1979), de galinha (KOIDE et al., 1982), de avestruz (Frost et al., 2002), humana (THALER E SCHMER, 1975), de zebrafish (HANUMANTHAiAH et al., 2002) e de salmão (ANDERSEN et al., 2000). 


\subsubsection{Espectrometria de massa (MALDI-TOF)}

As seqüências peptídicas obtidas por espectrometria de massa estão listadas na tabela 4.

Tabela 4. Identificação de peptídeos da antitrombina de $B$. jararaca por MALDI-TOF.

\begin{tabular}{cc}
\hline Sequência peptídica & Massa (Da) \\
\hline DFSSR & 610,285 \\
ITSASSQTLR & 1062,560 \\
FAHLLDQVSR & 1184,640 \\
LSSEVEDPPPYLMMDELLGR & 2290,077 \\
ANQTSVGCTQLVLVEGLSK & 2392,094 \\
\hline
\end{tabular}

As seqüências peptídicas obtidas e as seqüências das antitrombinas previamente descritas não apresentaram homologia significativa.

\subsection{8. "Western blotting"}

O método "Western blotting" foi utilizado para verificar a ocorrência de reação imunológica cruzada entre a antitrombina isolada de $B$. jararaca e a antitrombina de outros animais vertebrados. Esses experimentos foram realizados com plasma de peixe, rã, serpente não-peçonhenta, galinha, coelho e homem. 
O perfil protéico do plasma destes animais foi analisado através de eletroforese em gel de poliacrilamida, podendo ser observado na figura 17.

Experimentos de "Western blotting", utilizando-se anticorpos policlonais antiantitrombinade B. jararaca, apresentaram reação imunológica entre as antitrombinas de peixe, rã, serpente não-peçonhenta, galinha e humana, enquanto nenhuma reação foi verificada entre o anticorpo anti-antitrombina e a antitrombina de coelho (figura 18). 


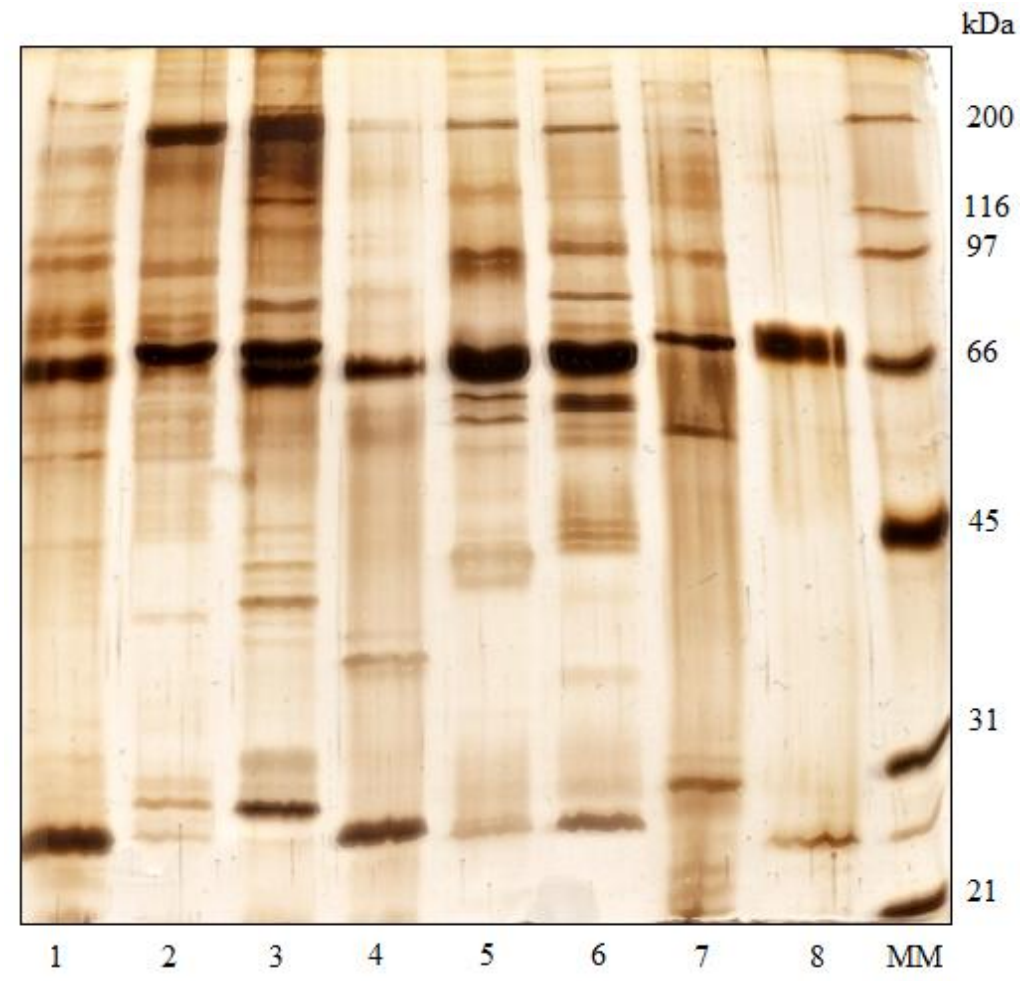

Figura 17. SDS-PAGE (10\%) do plasma de diversos animais e de antitrombina de B. jararaca. Sob condições reduzidas ( $1 \mu \mathrm{g}$ de proteína) sob condições reduzidas. As proteínas foram coradas com nitrato de prata. Canaleta (1) plasma de peixe (Salminus hilarii), (2) plasma de rã (Rana catesbeiana), (3) plasma de serpente não-peçonhenta (Oxyrhopus guibei), (4) plasma de galinha (Gallus gallus), (5) plasma de coelho (Oryctogalus cuniculus), (6) plasma humano, (7) plasma de B. jararaca, (8) antitrombina de $B$. jararaca, $(\mathrm{MM})$ marcador de massa molecular $($ BioRad) $(10 \mu \mathrm{L})$, do maior para o menor e com massa molecular de: miosina (200 kDa), $\beta$-galactosidade (116 kDa), fosforilase b (97 kDa), albumina (66 kDa), ovoalbumina (45 kDa), anidrase carbônica (31 kDa) e inibidor de tripsina (21 kDa). 


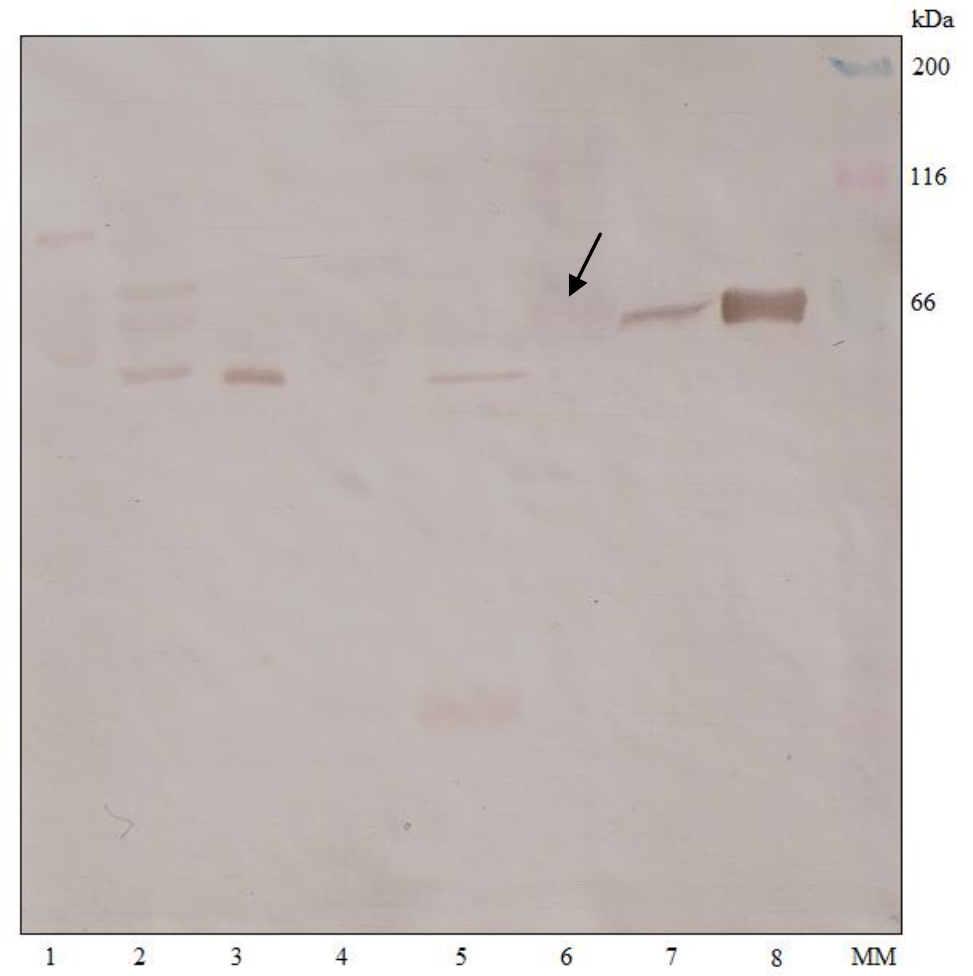

Figura 18. "Western blotting" utilizando-se plasma de diversos animais e antitrombina de B. jararaca (12 $\mu \mathrm{g}$ de proteína). As proteínas foram fracionadas através de SDS-PAGE (10\%), em condições reduzidas, transferidas para uma membrana de nitrocelulose e reveladas utilizando-se anticorpo policlonal antiantitrombina de B. jararaca. Linhas (1) plasma de peixe (Salminus hilarii), (2) plasma de rã (Rana catesbeiana), (3) plasma de galinha (Gallus gallus), (4) plasma de coelho (Oryctogalus cuniculus), (5) plasma humano, (6) plasma de serpente não-peçonhenta (Oxyrhopus guibei), (7) plasma de B. jararaca, (8) antitrombina de B. jararaca, (MM) marcador de massa molecular (BioRad) (10 $\mu \mathrm{L})$, do maior para o menor e com massa molecular de: miosina (200 kDa), $\beta$-galactosidade (116 kDa), fosforilase b (97 kDa), albumina (66 kDa), ovoalbumina (45 kDa), anidrase carbônica (31 kDa) e inibidor de tripsina (21 kDa). A seta indica a baixa reação imunológica entre a antitrombina de $B$. jararaca e a antitrombina de serpente não-peçonhenta. 


\section{Discussão}

A origem molecular da especificidade das proteases, sua regulação e seu desenvolvimento evolutivo permanecem, em sua maior parte, indefinidos. A elucidação desses aspectos é crucial para a correlação estrutura-função e para o desenvolvimento de inibidores mais específicos e potentes para fins farmacológicos. Desta forma, estudos a respeito destas enzimas, em especial da trombina, têm sido objeto de intenso estudo, com o intuito de descobrir as suas ações e como controlá-las. Acredita-se que o conhecimento do mecanismo de ação da trombina e o controle de sua atividade podem auxiliar na obtenção de inibidores específicos desta enzima, possibilitando o tratamento de doenças decorrentes de uma ação amplificada e descontrolada da trombina.

Evidências bioquímicas e moleculares indicam que a coagulação sangüínea resultante do fator tissular, da protrombina e do fibrinogênio está presente em todos os vertebrados e evoluiu antes da divergência dos tetrápodes e teleósteos há mais de 430 milhões de anos (DoOLITTLE, 1993).

Um dos métodos para se estudar a evolução da coagulação sangüínea é através da purificação e caracterização dos fatores de coagulação (DOOLITTLE, 1993). Este trabalho descreve a purificação e caracterização da antitrombina, o principal inibidor fisiológico da trombina, da serpente B. jararaca.

A antitrombina de B. jararaca foi isolada utilizando-se cromatografia de afinidade HiTrap Heparin HP. A estratégia de purificação da antitrombina do plasma dessa serpente foi muito eficiente, permitindo a obtenção desta proteína pura utilizando-se apenas um passo 
cromatográfico. Processo similar também foi empregado para isolar esse inibidor do plasma humano, apresentando comportamento semelhante. A antitrombina de diversos vertebrados também foi isolada através de processos cromatográficos baseados na afinidade do inibidor pela heparina, apresentando como ligante esta glicosaminoglicana. Esses resultados, por si só, indicam que as antitrombinas previamente descritas e a antitrombina de $B$. jararaca apresentam propriedades bioquímicas e funcionais semelhantes, considerando-se sua afinidade pela heparina.

Aproximadamente $25 \%$ da atividade da antitrombina presente no plasma foi recuperada. Entretanto, a recuperação real deve ser um pouco maior, considerando-se que o plasma de $B$. jararaca pode conter outros inibidores de trombina como o cofator de heparina II, por exemplo, que poderiam inibir a atividade da trombina durante a dosagem de atividade da antitrombina presente no plasma, interferindo no cálculo da recuperação do inibidor em estudo. Outro inibidor de trombina presente no plasma de B. jararaca é o BjI, porém, nesse caso, não podemos considerar sua participação na inibição da trombina, uma vez que ele inibe especificamente a atividade coagulante da trombina mas não interfere em sua atividade agonista na agregação nem em sua atividade amidolítica (TANAKA-AZEVEDO et al., 2003). Assim, como o método para dosagem é feito utilizando-se substrato cromogênico, não ocorre a interferência do BjI.

Pouco se sabe acerca do papel fisiológico da antitrombina em não-mamíferos. Utilizandose os dados obtidos através da tabela de purificação da antitrombina de $B$. jararaca, a concentração de antitrombina circulante dessa serpente foi estimada em $188 \mu \mathrm{g} / \mathrm{mL}$ de plasma, sendo este valor comparável à concentração de antitrombina no plasma humano $(150 \mu \mathrm{g} / \mathrm{mL})$ (CONARD et al., 1983). LEWIS (1996) demonstrou que o único fator da coagulação sangüínea presente em concentrações semelhantes em répteis e humanos é o fibrinogênio, enquanto os 
demais estão presentes em concentrações muito baixas nos répteis. Entretanto, este autor verificou que a concentração de antitrombina de crocodilos é semelhante à de humanos, sendo o mesmo observado para a serpente em estudo. Os répteis apresentam baixa pressão sanguínea e são, normalmente, letárgicos em seus movimentos. Seu sangue arterial circula em condições semelhantes àquelas encontradas no leito venoso de mamíferos, o que favoreceria a ocorrência de coagulação intravascular. Entretanto, FINLAYSON et al. (1962) verificaram que a formação de ateromas é um evento raro nos répteis. Dessa forma, é possível que a presença de anticoagulantes naturais, que permitam que a coagulação ocorra somente com a exposição do fator tissular após uma lesão, seja particularmente importante para os répteis (HACKETT E HANN, 1967). Além disso, esses animais não possuem superfícies delicadamente vascularizadas, como brânquias ou pele respiratória, o que exigiria mecanismos de coagulação mais rápidos.

O teste de coagulação revelou que a antitrombina de B. jararaca, in vitro, tem comportamento semelhante às demais antitrombinas já descritas: inibe a trombina quase que instanteneamente na presença de heparina mas na sua ausência essa inibição é muito lenta. Essa retenção da especificidade de ligação à heparina encontrada em todos os vertebrados confirma a importância central da antitrombina na anticoagulação dependente da heparina. JORDAN (1983) demonstrou que esta é uma propriedade comum à antitrombina dos vertebrados e o mesmo autor sugere que a relação entre a antritrombina e a heparina foi estabelecida em um ponto remoto da evolução da coagulação sangüínea e tem sido altamente conservada desde então. É interessante lembrar que foi verificada a presença de heparina em espécies primitivas de invertebrados. Os moluscos possuem uma molécula heparina-símile que, quando isolada e avaliada, apresenta atividade anticoagulante semelhante à da heparina de mamíferos (CASSARO E DIETRICh, 1977), indicando que essas heparinas de invertebrados possuem uma sequência de ligação à trombina 
semelhante à de mamíferos. Entretanto, a inibição da coagulação (ou equivalente) dependente de heparina não é observada em invertebrados, o que sugere que a participação da heparina na anticoagulação através da interação específica com a antitrombina (ou antitrombina-símile) é um evento que foi estabelecido durante a evolução do sistema de coagulação.

A antitrombina foi isolada e sua estrutura primária foi determinada de diversas espécies de vertebrados - homem (THALER E SCHMER, 1975; KoIDE, 1979), chipanzé, sapo (JoRDAN, 1983), boi, cavalo (Thaler E SChMER, 1975), ovelha (DAmus E WALlace, 1974), coelho, rato, galinha (KoIDE, 1979), hamster (MAK et al., 1996), avestruz (Frost et al., 2002) e salmão (ANDERSEN et al., 2000). Em todas as espécies descritas, esse inibidor apresenta as mesmas propriedades funcionais e fisico-químicas. Trata-se de uma glicoproteína com teor de carboidrato variado e massa molecular em torno de $60 \mathrm{kDa}$, com exceção da antitrombina de cachorro, com massa molecular de $77 \mathrm{kDa}$ (DAmUS E WALLACE, 1974).

Através de eletroforese em gel de poliacrilamida (gradiente 5-12\%), a antitrombina purificada de B. jararaca apresentou massa molecular de $61 \mathrm{kDa}$ composta por uma única cadeia polipeptídica, sendo favoravelmente comparada às massas descritas para outras espécies (tabela $5)$. 
Tabela 5. Massa molecular da antitrombina de diversos animais.

\begin{tabular}{lcc}
\hline Antitrombina & Massa Molecular (kDa) & Referência \\
\hline B. jararaca & $\mathbf{6 1}$ & (DE MORAIS et al., 2009) \\
Cavalo & 52,5 & (KURACHI et al., 1976) \\
Boi & 56,6 & (KURACHI et al., 1976) \\
Ovelha & 57 & (JORDAN, 1983) \\
Sapo & 58 & (JORDAN, 1983) \\
Homem & 58 & (THALER E SCHMEr, 1975; KOIDE, 1979) \\
Chipanzé & 59 & (JORDAN, 1983) \\
Avestruz & 59,2 & (FROST et al., 2002) \\
Coelho & 59,5 & (KoIDE, 1979) \\
Galinha & 60 & (KOIDE, 1979; KoIDE et al., 1982) \\
Tartaruga & 62 & (JORDAN, 1983) \\
Hamster & 62,5 & (MAK et al., 1996) \\
Cachorro & 77 & (DAMUS E WALLACE, 1974) \\
\hline
\end{tabular}

A focalização isoelétrica da antitrombina de B. jararaca indicou um pI ácido, de 4,5, sendo este valor, também, favoravelmente comparado aos outros valores de pI previamente descritos para este inibidor - 5,4-5,2 para a antitrombina humana (REIF E FREITAG, 1994), 4,95-5,25 para a de hamster (MAK et al., 1996), 4,5-5,0 para a bovina (NORDENMAN et al., 1977) 5,2-6,0 para a de avestruz (FrOST et al., 2002) e 4,7-6,0 para a de salmão (ANDERSEN et al., 2000).

Este inibidor foi analisado quanto à sua natureza química, visando detectar a presença de açúcares na antitrombina de $B$. jararaca, utilizando-se a metodologia descrita por FAIRBANKS et al. (1971), em que os carboidratos reagem com o reativo de Schiff. Os resultados mostraram que 
a cadeia polipeptídica apresenta carboidratos ligados à sua estrutura, sendo portanto uma glicoproteína. A deglicosilação através de ácido TFMS resultou em uma mudança da massa molecular desse inibidor de 61 para $50 \mathrm{kDa}$, sendo seu conteúdo total de carboidrato estimado em 18\%. Este valor é maior que o de humanos (9\%), bovinos (12\%) e eqüinos (16\%) (KURACHI $e t$ al., 1976). Entretanto, o conteúdo de carboidrato estimado para galinha (17,5\%) (KoIDE et al., 1982) é similar ao de B. jararaca, enquanto o de salmão é maior (19,7\%) (ANDERSEN et al., 2000)

JORDAN (1983) e KOIDE et al. (1979) demonstraram que a reação imunológica cruzada entre as antitrombinas da maioria das espécies de vertebrados é mínima. Entretanto, ensaios imunológicos demonstraram que anticorpos policlonais anti-antitrombina de $B$. jararaca reconhecem este inibidor presente em peixe, rã, serpente não-peçonhenta, galinha e humanos, embora, curiosamente, esse reconhecimento seja mínimo no plasma da serpente não-peçonhenta Oxyrhopus guibei. Esses resultados corroboram os obtidos por KURACHI et al. (1976) que demonstraram existir relação imunológica entre a antitrombina de humanos, bovinos e eqüinos. Também é interessante notar que nenhuma reação imunológica foi verificada no plasma de coelho, apesar da alta similaridade econtrada entre a sequiência de aminoácidos da região aminoterminal da antitrombina de B. jararaca e de coelhos, o que sugere que essas duas antitrombinas, mesmo que bioquimicamente semelhantes, apresentam diferentes epítopos antigênicos.

A seqüência de parte da região amino-terminal obtida para a antitrombina de $B$. jararaca (10 aminoácidos) é similar às já descritas para as outras antitrombinas. Quando esta seqüência é comparada às demais seqüências previamente determinadas a maior similaridade (70\%) é encontrada com a antitrombina de coelhos (sete resíduos de aminoácidos em comum). Baseados 
na homologia da seqüência de aminoácidos, HUNT E DAYHOFF (1980) sugeriram que os inibidores plasmáticos de proteases divergiram de um ancestral comum há aproximadamente 500 milhões de anos. JORDAN (1983) sugere que há 350-400 milhões de anos certos elementos da antitrombina já estariam bem estabelecidos. A alta conservação entre as antitrombinas descritas, incluindo a de B. jararaca, corrobora o estudo de JORDAN (1983) e é ilustrada pela alta homologia (70\%) entre a região amino-terminal de salmonídeos e humanos, apesar da significativa distância evolutiva (SALTE et al., 1995).

A histidina foi determinada como o primeiro resíduo de aminoácido da região aminoterminal da antitrombina de B. jararaca. A maioria das antitrombinas já descritas apresentam o mesmo resíduo nessa posição, com exceção da antitrombina de galinha (KOIDE, 1979; KoIDE et al., 1982), que apresenta um resíduo de alanina, e da antitrombina de hamster (MAK et al., 1996) e rato (KOIDE, 1979), que apresentam um resíduo de asparagina. É importante notar que o resíduo de aminoácido presente na segunda posição da região amino-terminal é altamente variável entre as espécies: glicina para humanos (THALER E SCHMER, 1975), triptofano para eqüinos (THALER E SCHMER, 1975) e suínos (KoIDE, 1979), arginina para bovinos (ThAlER E SCHMER, 1975) e ovelha (OLSON E BJORK, 1994), prolina para hamster (MAK et al., 1996), rato (KOIDE, 1979) e galinha (KoIDE, 1979) e ácido glutâmico para coelho (KOIDE, 1979), avestruz (FrOST et al., 2002) e B. jararaca. KOIDE et al. (1982) sugeriram que essa região hipervariável poderia ser um dos sítios de determinação antigênica na antitrombina. Entretanto, esta hipótese não foi confirmada pelos nossos resultados, uma vez que não foi observada relação imunológica entre a antitrombina de B. jararaca e a de coelho, mesmo estes dois inibidores apresentando o mesmo resíduo de aminoácido na segunda posição da região amino-terminal. 
Apesar da análise por espectrometria de massa não ter fornecido a seqüência completa da antitrombina de B. jararaca, algumas seqüências peptídicas foram obtidas. Entretanto, essas seqüências não apresentaram homologia significativa com as outras seqüências descritas, diferentemente do que foi observado para a sequiência de aminoácidos da região amino-terminal obtida por degradação de Edman. Além disso, a ausência de informação a respeito da seqüência da antitrombina de répteis dificultou a análise comparativa do inibidor isolado de $B$. jararaca.

Os resultados obtidos sugerem que a antitrombina de $B$. jararaca, devido às suas características bioquímicas e imunológicas, apresenta é semelhante às antitrombinas presentes em outras espécies. Considerando-se que as serpinas evoluíram a partir de um ancestral comum há mais de 500 milhões de anos (CARRELl et al., 1987), este fato não é surpreendente. Estas características confirmam que a antitrombina presente nesta serpente desempenha uma importante função na hemostasia desses répteis. 


\section{Conclusões}

1. A antitrombina da serpente $B$. jararaca apresenta-se sob a forma de uma única cadeia polipeptídica com massa molecular de $61 \mathrm{kDa}$, conteúdo total estimado de carboidrato de $18 \%$ e ponto isoelétrico de 4,5 .

2. A sequência de aminoácidos da região amino-terminal da antitrombina de $B$. jararaca é bastante semelhante às previamente descritas para outros animais

3. A velocidade de inibição da trombina pela antitrombina de $B$. jararaca é aumentada na presença de heparina, sendo este comportamento semelhante ao das demais antitrombinas descritas.

4. Anticorpos anti-antitrombina de B. jararaca reconhecem este inibidor presente no plasma de peixes (Salminus hilarii), anfíbios (Rana catesbeiana), répteis (Oxyrhopus guibei), aves (Gallus gallus) e mamíferos (Homo sapiens sapiens), apesar de nenhuma reação imunológica ter sido verificada entre o anticorpo anti-antitrombina de $B$. jararaca e a antitrombina de coelho (Oryctogalus cuniculus).

5. Os resultados obtidos sugerem que a antitrombina de $B$. jararaca, devido às suas características bioquímicas, funcionais e imunológicas, é semelhante às antitrombinas descritas em outras espécies. Estas características confirmam a importante função da antitrombina da serpente $B$. jararaca na hemostasia destes animais. 


\section{Resumo}

A trombina é uma enzima chave do sistema de coagulação, que ativa as plaquetas, converte o fibrinogênio em fibrina e amplifica sua própria geração pela ativação dos fatores V, VII e XI. A geração e a ação precisas dessa enzima, balanceadas pelos inibidores nos vasos lesados, é o resultado de uma série complexa de reações denominadas de coagulação sangüínea. Assim, a presença desses inibidores específicos tem papel fundamental.

Uma das moléculas mais importantes na regulação da trombina é a antitrombina, uma glicoproteína plasmática que atua como um importante inibidor da coagulação sangüínea através da inativação da trombina e de outras serinoproteases, como os fatores $\mathrm{IX}_{\mathrm{a}}, \mathrm{X}_{\mathrm{a}}, \mathrm{XI}_{\mathrm{a}}$ e $\mathrm{XII}_{\mathrm{a}}$. Em humanos, esse inibidor é responsável por aproximadamente $80 \%$ da atividade inibitória sobre essa enzima. A atividade da antitrombina é extremamente afetada pela sua interação com a heparina, o que aumenta grandemente a velocidade da reação de inativação.

O objetivo deste trabalho foi isolar e caracterizar a antitrombina da serpente Bothrops jararaca (B. jararaca) e compará-la com outras antitrombinas já descritas.

A antitrombina foi purificada do plasma da serpente $B$. jararaca através de um passo cromatográfico em coluna de afinidade HiTrap Heparin HP. Sua concentração plasmática foi estimada em cerca de $188 \mu \mathrm{g} / \mathrm{mL}$. Os resultados obtidos mostraram que este inibidor é uma glicoproteína de cadeia única de $61 \mathrm{kDa}$, ponto isoelétrico de 4,5 e conteúdo total estimado de carboidrato de $18 \%$. Os aminoácidos da região amino-terminal da antitrombina de $B$. jararaca foram analisados e a seqüência obtida (His-Glu-Ser-Ser-Val-Gln-Asp-Ile-Ile-Thr) mostrou-se 
bastante similar às previamente descritas para outros animais. Ensaios imunológicos demonstraram que anticorpos policlonais anti-antitrombina de B. jararaca produzidos em camundongos reconhecem este inibidor presente em peixes (Salminus hilarii), anfíbios (Rana catesbeiana), répteis (Oxyrhopus guibei), aves (Gallus gallus) e mamíferos (Homo sapiens sapiens).

O teste de coagulação in vitro revelou que a antitrombina de $B$. jararaca tem comportamento semelhante às demais antitrombinas já descritas: inibe a trombina quase que instantaneamente na presença de heparina mas na sua ausência essa inibição é muito lenta. A antitrombina de $B$. jararaca apresentou atividade inibitória sobre a coagulação da serpente $B$. jararaca e de bovinos e sobre o substrato cromogênico H-D-Phe-Pip-Arg- $p$ NA (S-2238 Chromogenix).

Os resultados obtidos sugerem que a antitrombina de $B$. jararaca, devido às suas características bioquímicas e imunológicas, apresenta semelhanças às antitrombinas descritas em outras espécies. Estas características confirmam a importante função da antitrombina da $B$. jararaca na hemostasia destes animais. 


\section{Abstract}

Thrombin is a key enzyme of blood system, which activates the platelets, converts fibrinogen into fibrin and amplifies its self-generation by activation of factors V, VIII and XI. Its inhibitors, inside the injured vessel, also control the precise and balanced generation of this enzyme, as a result of a complex series of reactions named blood coagulation. So, thrombin specific inhibitors have an essential role upon its regulation, since modulation of thrombin production is important to maintain haemostasis under physiolocal conditions.

One of the most important molecules regulating thrombin activity is antithrombin, a plasma glycoprotein that works as a potent inhibitor of blood coagulation by inactivating thrombin and other serine proteases including $\mathrm{FIX}_{\mathrm{a}}, \mathrm{FX}_{\mathrm{a}}, \mathrm{FXI}_{\mathrm{a}}$ and $\mathrm{FXII}_{\mathrm{a}}$. Antithrombin is responsible for approximately $80 \%$ of the thrombin inhibitory capacity on human plasma. Control of the action of antithrombin is affected through its interaction with the co-factor heparin.

The objectives of this work were to purify and to characterize Bothrops jararaca (B. jararaca) antithrombin and to compare it with other antithrombins described.

Antithrombin was purified from $B$. jararaca plasma by affinity chromatography using HiTrap Heparin HP column. Its concentration in $B$. jararaca plasma is about $188 \mu \mathrm{g} / \mathrm{mL}$. This inhibitor is a single-chain glycoprotein with $61 \mathrm{kDa}$, an acidic isoelectric point (4.5) and a total carbohydrate content of $18 \%$. Its amino-terminal sequence has been determined as His-Glu-SerSer-Val-Gln-Asp-Ile-Ile-Thr, which is highly homologous to the amino-terminal sequences of other animal antithrombins, indicating high amino acid conservation among several animals. 
Immunological cross-reactivity was observed between anti- $B$. jararaca antithrombin antibodies and antithrombin from fish (Salminus hilarii), amphibian (Rana catesbeiana), reptile (Oxyrhopus guibei), avian (Gallus gallus) and mammalian (Homo sapiens sapiens). B. jararaca antithrombin showed inhibitory activity upon bovine and B. jararaca coagulation and amidolytic substrate $\mathrm{H}$ D-Phe-Pip-Arg- $p$ NA (S-2238 - Chromogenix).

The results obtained from this study confirmed that $B$. jararaca antithrombin is closely related to the corresponding molecule of other species considering its biochemical and physiological characteristics. From these properties it is concluded that $B$. jararaca antithrombin fulfill an important function in blood coagulation, similar to that of its counterparts in other vertebrates. 


\section{Apêndice A - Abreviaturas}

$\mathrm{A}_{\lambda}$ - absorbância no comprimento de onda $\lambda(\mathrm{nm})$

AT - antitrombina

$\mathrm{Bj}$ - Bothrops jararaca

B. jararaca-Bothrops jararaca

BSA - soroalbumina bovina

DAB - 3,3-diaminobenzidina

FB - fibrinogênio bovino

FBj - fibrinogênio de Botrhops jararaca

$g$ - aceleração da gravidade

GAG - glicosaminoglicana

HMWK - cininogênio de alta massa molecular

L - litro, com seus múltiplos e submúltiplos

m - metro, com seus múltiplos e submúltiplos

$\mathrm{mA}$ - milliampère

MM - massa molecular

$\mathrm{NaCl}$ - cloreto de sódio

$\mathrm{nm}$ - nanômetro

N-terminal - aminoterminal

OPD - orto-fenilenodiamina (1,2-benzenodiamina)

p/v - concentração expressa pela relação entre peso e volume de substâncias

PAGE - eletroforese em gel de poliacrilamida 
PBS - tampão fosfato de sódio

pNA - para-nitroanilida

PVDF - difluoreto de polivinidileno

SDS - dodecil sulfato de sódio

Serpinas - inibidores de serinoproteases

t.a. - temperatura ambiente

TEMED - N,N,N',N'tetrametil 1,2-diaminometano

TFPI - inibidor de fator tissular

TFMS - trifluorometanossulfônico

Tris - tris(hidroximetil)-aminometano

$\mathrm{U}$ - unidade

v/v - concentração expressa pela relação de volumes entre substâncias 
10. Apêndice B - Símbolos dos aminoácidos

\begin{tabular}{|c|c|c|}
\hline Aminoácido & Símbolo com três letras & Símbolo com uma letra \\
\hline Alanina & Ala & $\mathrm{A}$ \\
\hline Arginina & Arg & $\mathrm{R}$ \\
\hline Asparagina & Asn & $\mathrm{N}$ \\
\hline Ácido aspártico & Asp & $\mathrm{D}$ \\
\hline Asparagina ou ácido aspártico & Asx & $\mathrm{B}$ \\
\hline Cisteína & Cys & $\mathrm{C}$ \\
\hline Glutamina & Gln & Q \\
\hline Ácido glutâmico & Glu & $\mathrm{E}$ \\
\hline Glutamina ou ácido glutâmico & Glx & $\mathrm{Z}$ \\
\hline Glicina & Gly & $\mathrm{G}$ \\
\hline Histidina & His & $\mathrm{H}$ \\
\hline Isoleucina & Ile & $\mathrm{I}$ \\
\hline Leucina & Leu & $\mathrm{L}$ \\
\hline Lisina & Lys & $\mathrm{K}$ \\
\hline Metionina & Met & M \\
\hline Finilalanina & Phe & $\mathrm{F}$ \\
\hline Prolina & Pro & $\mathrm{P}$ \\
\hline Serina & Ser & $\mathrm{S}$ \\
\hline Treonina & Thr & $\mathrm{T}$ \\
\hline Triptofano & Trp & W \\
\hline Tirosina & Tyr & $\mathrm{Y}$ \\
\hline Valina & Val & V \\
\hline
\end{tabular}




\section{Referências bibliográficas}

Abildgandd, C. F.; Corrigan, J. J.; Seeler, R. A.; Simone, J. V.; Schulman, I. Meningococcemia associated with intravascular coagulation. Pediatrics, v. 40, n. 1, p. 78-83, 1967.

Andersen, O.; Flengsrud, R.; NorberG, K.; SAlte, R. Salmon antithrombin has only three carbohydrate side chains, and shows functional similarities to human beta-antithrombin. European Journal of Biochemistry, v. 267, n. 6, p. 1651-7, 2000.

ARCHER, R. K. Blood coagulation in non-human vertebrates. In: MACFARLANE, R. G. The haemostatic mechanism in man and other animal. London: Academic Press, p. 121-9, 1970.

Arocha-PiñAngo, C. L. G.; OJEDA, A. The blood clotting mechanism of spectacled caiman Caiman crocodilus. Molecular Physiology, v. 2, p. 161-170, 1982.

Barrett, A. J. An introduction to the proteinases. In: Barrett, A. J. E. S. (Ed.). Proteinase Inhibitors. New York: Elsevier, p. 3-22, 1986.

BAJZAR, L. Thrombin activable fibrinolyses inhibitor and an antithrombotic pathway. Arteriosclerosis, thrombosis, and vascular biology, v. 20, p. 2511-18, 2000. 
Belamarich, F. A.; Eskridge, R. W. Eleventh Annual Symposium on Blood: Some observations on clotting in alligators. Thrombosis et Diathesis Haemorrhagica, v. 9, p. 223-224, 1963.

Blum, H.; BeIER, H.; GROSS, H. J. Improved silver staining of plant proteins, RNA and DNA in polyacrylamide gels. Electrophoresis, v. 8, p. 93-99, 1987.

BOURIN, M. C.; LINDAHL, U. Glycosaminoglycans and the regulation of blood coagulation. The Biochemical Journal, v. 289, p. 313-30, 1993.

Brennan, S. O.; GeORge, P. M. e JoRdAn, R. E. Physiological variant of antithrombin-III lacks carbohydrate sidechain at Asn 135. FEBS Letters, v. 219, n. 2, p. 431-6, 1987.

BROZE, G. J.; MAJERUS, P. W. Purification and properties of human coagulation factor VII. The Journal of Biological Chemistry, v. 255, n. 4, p. 1242-7, 1980.

CADLE, J. E. Geographic distribution: problems in phylogeny and zoogeography. In: Seiger, R. A., Collins, J. T. e Novak, S. S. (Ed.). Snakes: ecology and evolutionary biology. New York: McGraw-Hill, p. 77-105, 1987.

Campbell, J. A.; Lamar, W. W. The venomous reptiles of Latin America. New York: Cornell University Press, 1989, 425 p. 
CARrel, R. W. T. Alpha 1-antitrypsin and the serpins: variation and countervariation. Trends in Biochemical Sciences, v. 10, p. 20-4, 1985.

Carrell, R. W.; Gooptu, B. Conformational changes and disease-serpins, prions and Alzheimer's. Current Opinion in Structural Biology, v. 8, n. 6, p. 799-809, 1998.

Carrell, R. W.; Pemberton, P. A.; Boswell, D. R. The serpins: evolution and adaptation in a family of protease inhibitors. Cold Spring Harbor Symposia on Quantitative Biology, v. 52, p. 527-35, 1987.

Cassaro, C. M.; Dietrich, C. P. Distribution of sulfated mucopolysaccharides in invertebrates. The Journal of Biological Chemistry, v. 252, n. 7, p. 2254-61, 1977.

ChromogeniX. Antithrombin - Product Monography. 1995.

ChUdZINSKI, A. M. Isolamento e caracterização de um inibidor de cisteíno-proteinases do plasma de Bothrops jararaca. Departamento de Bioquímica, Escola Paulista de Medicina, 1989.

Collen, D. The plasminogen (fibrinolytic) system. Thrombosis and Haemostais, v. 82, p.259$70,1999$.

Collen, D.; Schetz, J.; De Cock, F.; Holmer, E.; Verstraete, M. Metabolism of antithrombin III (heparin cofactor) in man: effects of venous thrombosis and of heparin administration. European Journal of Clinical Investigation, v. 7, n. 1, p. 27-35, 1977. 
Colman, R. W.; Marder, V. J.; Salzman, E. W.; Hirsh, J. Overview of Hemostasis. In: Colman, R. W.; Hirsh, J.; Marder, V. J.; Salzman, E. W. (Ed.). Hemostasis and thrombosis: basic principles and clinical practice. Philadelphia: Lippincott Company, p. 3-18, 1994.

Conard, J.; Brosstad, F.; Lie Larsen, M.; SAmama, M.; AbildgaARd, U. Molar antithrombin concentration in normal human plasma. Haemostasis, v. 13, n. 6, p. 363-8, 1983.

DAHLBACK, B. The protein $\mathrm{C}$ anticoagulant system: inherited defects as basis for venous thrombosis. Thrombosis Research, v. 77, n. 1, p. 1-43, 1995.

DAHLBACK, B. Procoagulant and anticoagulant properties of coagulation factor $\mathrm{V}$ : factor $\mathrm{V}$ Leiden (APC resistance) causes hypercoagulability by dual mechanisms. The Journal of Laboratory and Clinical Medicine, v. 133, n. 5, p. 415-22, 1999.

DAHLBACK, B. Blood coagulation. Lancet, v. 355, n. 9215, p. 1627-32, 2000.

Damus, P. S.; Wallace, G. A. Purification of canine antithrombin III-heparin cofactor using affinity chromatography. Biochemistry and Biophysical Research Communications, v. 61 , n. 4 , p. $1147-53,1974$. 
Davidson, C. J.; Hirt, R. P.; Lal, K.; Snell, P.; Elgar, G.; Tuddenham, E. G.; McVey, J. H. Molecular evolution of the vertebrate blood coagulation network. Thrombosis and Haemostais, v. 89, n. 3, p. 420-8, 2003.

DAVIE, E. W.; FuJIKAWA, K.; KISIEL, W. The coagulation cascade: initiation, maintenance, and regulation. Biochemistry, v. 30, n. 43, p. 10363-70, 1991.

De Morais, K. B.; Grego, K. F.; TAnaKa-Azevedo, A. M. Identification of proteins similar to Bothrops jararaca coagulation inhibitor $(\mathrm{BjI})$ in the plasmas of Bothrops alternatus, Bothrops jararacussu and Crotalus durissus terrificus snakes. Comparative Biochemistry and Physiology, v. 149, n. 2, p. 236-40, 2008.

De Morais, K. B.; Vieira, C. O.; Hirata, I. Y.; TAnakA-Azevedo, A. M. Bothrops jararaca antithrombin: isolation, characterization and comparison with other animal antithrombins. Comparative Biochemistry and Physiology, v. 152, n. 2, p. 171-6, 2009.

DENSON, K. W. The clotting of a snake (Crotalus viridis helleri) plasma and its interaction with various snake venoms. Thrombosis and Haemostasis, v. 35, n. 2, p. 314-23, 1976.

Didisheim, P.; HATTORI, K.; LEWIS, J. H. Hematologic and coagulation studies in various animal species. The Journal of Laboratory and Clinical Medicine, v. 53, p. 866-875, 1959. 
DoolitTLE, R. F. The evolution of vertebrate blood coagulation: a case of Yin and Yang. Thrombosis and Haemostasis, v. 70, n. 1, p.24-8, 1993.

DoolitTLE, R. F.; Feng, D. F. Reconstructing the evolution of vertebrate blood coagulation from a consideration of the amino acid sequences of clotting proteins. Cold Spring Harbor Symposia on Quantitative Biology, v. 52, p. 869-74, 1987.

Edge, A. S.; Faltynek, C. R.; Hof, L.; Reichert, L. E.; Weber, P. Deglycosylation of glycoproteins by trifluoromethanesulfonic acid. Analytical Biochemistry, v. 118, n. 1, p. 131-7, 1981 .

Engelberg, H. Heparin: physiology and pathobiology. Pathobiology Annual, v. 8, n. 85-104, 1978.

ERDRÖS, E. G. M.; GRAHAM, W.J. Studies on the evolution of plasma kinins: reptilian and avian blood. Life Sciences, v. 39, p. 403-12, 1967.

Estes, R.; QeIROZ, K.; GAUthIER, J. Phylogenetic relationships within Squamata. In: Estes, R.; Pregill, G. (Ed.). Phylogenetic relationships of the lizard families. Standfort: Standfort University Press, 1988.

FAirbanks, G.; Steck, T. L.; WAllach, D. F. Electrophoretic analysis of the major polypeptides of the human erythrocyte membrane. Biochemistry, v. 10, n. 13, p. 260617, 1971. 
FAnTL, P. A. A comparative study of blood coagulation in vertebrates. The Australian Journal of Experimental Biology, v. 39, p. 403-12, 1961.

FERRAREZZI, H. Uma sinopse dos gêneros e classificação das serpentes (Squamata). In: Nascimento, L. (Ed.). Herpetologia no Brasil. Belo Horizonte: Fundação Ezequiel Dias, v. p. 69-80, 1994.

Finlayson, R.; Symons, C.; FIEnnes, R. N. Atherosclerosis: a comparative study. British Medical Journal, v. 1, n. 5277, p. 501-7, 1962.

Franco, F. L. Origem e diversidade de serpentes. In: CARdoso, J. L. C.; FranÇA, F. O. S.; Wen, F. H.; Malaque, C. M. S.; Haddad, V. (Ed.). Animais peçonhentos no Brasil. São Paulo: Sarvier-FAPESP, p. 13-32, 2003.

Frost, C. L.; NAUde, R. J.; Muramoto, K. Ostrich antithrombin III: kinetics and mechanism of inhibition of ostrich thrombin. The International Journal of Biochemistry and Cell Biology, v. 34, n. 9, p. 1164-71, 2002.

Frost, C. L.; Naude, R. J.; Oelofsen, W.; Jacobson, B. Comparative blood coagulation studies in the ostrich. Immunopharmacology, v. 45, n. 1-3, p. 75-81, 1999.

FurIE, B.; FurIE, B. C. Molecular and cellular biology of blood coagulation. The New England Journal of Medicine, v. 326, n. 12, p. 800-6, 1992. 
GAILANI, D.; BROZE, G. J. Factor XI activation in a revised model of blood coagulation. Science, v. 253 , n. 5022 , p. $909-12,1991$.

GENTRY, P. A. Comparative aspects of blood coagulation. Veterinary Journal, v. 168, n. 3, p. 238-51, 2004.

Gettins, P. G.; Fan, B.; Crews, B. C.; Turko, I. V.; Olson, S. T.; Streusand, V. J. Transmission of conformational change from the heparin binding site to the reactive center of antithrombin. Biochemistry, v. 32, n. 33, p. 8385-9, 1993.

GREENE, H. W. Snakes - the evolution of mystery in nature. Berkeley: University of California in Press, 1997, 351 p.

Grootenhuis, P. D.; Westerduin, P.; Meuleman, D.; Petitou, M.; Van Boeckel, C. A. Rational design of synthetic heparin analogues with tailor-made coagulation factor inhibitory activity. Nature Structural Biology, v. 2, n. 9, p. 736-9, 1995.

Hackett, E.; Hann, C. Slow clotting of reptile bloods. Journal of Comparative Pathology, v. 77, n. 2, p. 175-80, 1967.

Hanumanthaiah, R.; Day, K.; Jagadeeswaran, P. Comprehensive analysis of blood coagulation pathways in teleostei: evolution of coagulation factor genes and 
identification of zebrafish factor VIIi. Blood Cells, Molecules and Diseases, v. 29, n. 1, p. 57-68, 2002.

HaRLow, E.; LANE, D. Antibodies: a laboratory manual. New York: Cold Spring Harbor Laboratory, p. 471-510, 1988.

HunT, L. T.; DAYHOFF, M. O. A surprising new protein superfamily containing ovalbumin, antithrombin-III, and alpha 1-proteinase inhibitor. Biochemical and Biophysical Research Communications, v. 95, n. 2, p. 864-71, 1980.

IRving, J. A.; Pike, R. N.; LeSK, A. M.; Whisstock, J. C. Phylogeny of the serpin superfamily: implications of patterns of amino acid conservation for structure and function. Genome Research, v. 10, n. 12, p. 1845-64, 2000.

Irving, J. A.; Steenbakkers, P. J.; Lesk, A. M.; Op Den CAMP, H. J.; Pike, R. N.; Whisstock, J. C. Serpins in prokaryotes. Molecular Biology and Evolution, v. 19, n. 11, p. 1881-90, 2002.

IWANaga, S. Primitive coagulation systems and their message to modern biology. Thrombosis and Haemostasis, v. 70, n. 1, p. 48-55, 1993.

JACQUeS, F. A. Blood Coagulation and Anticoagulant Mechanisms in the Turtle Pseudemys elegans. Comparative Biochemistry and Physiology, v. 16, p. 241-9, 1963. 
Jagadeeswaran, P.; Sheehan, J. P. Analysis of blood coagulation in the zebrafish. Blood Cells, Molecules and Diseases, v. 25, n. 3-4, p. 239-49, 1999.

JiAnG, Y.; DoolitTLE, R. F. The evolution of vertebrate blood coagulation as viewed from a comparison of puffer fish and sea squirt genomes. Proceedings of the National Academy of Sciences of the United States, v. 100, n. 13, p. 7527-32, 2003.

JORDAN, R. E. Antithrombin in vertebrate species: conservation of the heparin-dependent anticoagulant mechanism. Archives of Biochemistry and Biophysics, v. 227, n. 2, p. 587-95, 1983.

Jordan, R. E.; Oosta, G. M.; GARDNER, W. T.; RosenberG, R. D. The binding of low molecular weight heparin to hemostatic enzymes. The Journal of Biological Chemistry, v. 255, n. 21, p. 10073-80, 1980.

KIRCHHOFER, D.; NEMERSON, Y. Initiation of blood coagulation: the tissue factor/factor VIIa complex. Current Opinion in Biotechnology, v. 7, n. 4, p. 386-91, 1996.

KoIDE, T. Isolation and characterization of antithrombin III from human, porcine and rabbit plasma, and rat serum. Journal of Biochemistry, v. 86, n. 6, p. 1841-50, 1979.

KoIDE, T.; OHTA, Y.; OdAnI, S.; ONO, T. Chicken antithrombin. Isolation, characterization, and comparison with mammalian antithrombins and chicken ovalbumin. Journal of Biochemistry, v. 91, n. 4, p. 1223-9, 1982. 
KURACHI, K.; SChMER, G.; Hermodson, M. A.; Teller, D. C.; DAvie, E. W. Characterization of human, bovine, and horse antithrombin III. Biochemistry, v. 15, n. 2, p. 368-73, 1976.

LAEMMLI, U. K. Cleavage of structural proteins during the assembly of the head of bacteriophage T4. Nature, v. 227, n. 259, p. 680-5, 1970.

Lavras, A. A. C. F., Hiraichi, E.; Boucault, M. A.; Tobo, T.; Schmuziger, R.; Nahas, L.; PICARELLI, Z. P. Deficiency of kalikrein-kinin system and presence of potent kininase activity in the plasma of Bothrops jararaca (Serpentes, Crotalinae). Ciência e Cultura, v. 31, p. $168-74,1979$.

Leon, M.; AiACH, M.; Coezy, E.; GuenneC, J. Y.; Fiessinger, J. N. Antithrombin III synthesis in rat liver parenchymal cells. Thrombosis Research, v. 30, n. 4, p. 369-75, 1983.

LEWIS, J. H. Comparative hemostasis: studies on elasmobranchs. Comparative Biochemistry and Physiology, v. 42, n. 1, p. 233-40, 1972.

LewIS, J. H. Class: Reptilia, Comparative Hemostasis in Vertebrates. The Reptiles. New York: Plenum Press, 1996, 426 p.

MAK, P.; ENGHILD, J. J.; DubIN, A. Hamster antithrombin III: purification, characterization and acute phase response. Comparative Biochemistry and Physiology, v. 115, n. 1, p. 13541, 1996. 
Marshall, C. J. Evolutionary relationships among the serpins. Philosophical Transactions of the Royal Society of London, v. 342, n. 1300, p. 101-19, 1993.

Melgarejo, A. R. Serpentes peçonhentas do Brasil. In: Cardoso, J. L. C.; FrançA, F. O. S.; Wen, F. H.; Malaque, C. M. S.; Haddad, V. (Ed.). Animais peçonhentos no Brasil. Biologia, clínica e terapêutica dos acidentes São Paulo: Sarvier - FAPESP, p. 33-61, 2003.

MinistÉRIO DA SAÚDE. Manual de diagnóstico e tratamento de acidentes por animais peçonhentos. Brasília, 2001, 120 p.

Nahas, L.; BetTi, F.; Kamiguti, A. S.; Martins, I. S. S. Blood coagulation mechanism in the snakes Waglerophis merremii and Bothrops jararaca. Comparative Biochemistry and Physiology, v. 69, p. 739-43, 1981.

Nahas, L.; BetTi, F.; KAmiguti, A. S.; SAto, H. Blood coagulation inhibitor in a snake plasma (Bothrops jararaca). Thrombosis et Diathesis Haemorrhagica, v. 30, n. 1, p. 106-13, 1973.

Nordenman, B.; Nystrom, C.; BJORK, I. The size and shape of human and bovine antithrombin III. European Journal of Biochemistry, v. 78, n. 1, p. 195-203, 1977. 
OliveIRA, E. P.; TANIZAKI, M. M. Effect of a proteinase inhibitor from the plasma of Bothrops jararaca on coagulant and myotoxic activities of Bothrops venoms. Toxicon, v. 30, p. 123-8, 1992.

OLSON, S. T.; BJORK, I. Regulation of thrombin activity by antithrombin and heparin. Seminars in Thrombosis and Hemostasis, v. 20, n. 4, p. 373-409, 1994.

PERRY, D. J. Antithrombin and its inherited deficiencies. Blood Reviews, v. 8, n. 1, p. 37-55, 1994.

Petersen, E. E. D.W.; Sottrup-Jensen, L.; Magnusson, S. The primary structure of antihrombin-III (heparin-cofactor): partial homology between alpha1-antitrypsin and antithrombin-III. In: Collen, D. W.; Verstraete, M. (Ed.). The physiological inhibitors of coagulation and fibrinolysis. Amsterdam: Elsevier, p. 43, 1979.

PIzzo, S. V. Serpin receptor 1: a hepatic receptor that mediates the clearance of antithrombin IIIproteinase complexes. The American Journal of Medicine, v. 87, n. 3B, p. 10S-14S, 1989.

Ponczek, M. B.; Gailani, D.; DoolitTle, R. F. Evolution of the contact phase of vertebrate blood coagulation. Journal of Thrombosis and Haemostasis, v. 6, n. 11, p. 1876-83, 2008. 
Potempa, J.; KorZus, E.; TRAVIS, J. The serpin superfamily of proteinase inhibitors: structure, function, and regulation. The Journal of Biological Chemistry, v. 269, n. 23, p. 1595760, 1994.

RAPAPORT, S. I. The extrinsic pathway inhibitor: a regulator of tissue factor-dependent blood coagulation. Thrombosis and Haemostasis, v. 66, n. 1, p. 6-15, 1991.

RatnofF, O. D.; Rosenberg, M. J.; Everson, B; EMAnuelson, M.; TUlodZiecki, N. Notes on clotting in a Burmese python (Python molurus bivittatus). The Journal of Laboratory and Clinical Medicine, v. 115, n. 5, p. 629-35, 1990.

ReIF, O. W.; Freitag, R. Control of the cultivation process of antithrombin III and its characterization by capillary electrophoresis. Journal of Chromatography, v. 680, n. 2, p. 383-94, 1994.

Renne, T.; Pozgajova, M.; Gruner, S.; Schuh, K.; Pauer, H. U.; Burfeind, P.; Gailani, D.; NIESWANDT, B. Defective thrombus formation in mice lacking coagulation factor XII. The Journal of Experimental Medicine, v. 202, n. 2, p. 271-81, 2005.

RIPPIEL, O. A review of the origin of snakes. In: Hecht, M., Wallace, B. e Prance, G. (Ed.). Evolutionary Biology. New York: Plenum, v. 22, p. 37-130, 1988.

Roberts, H. R.; LozIer, J. N. New perspectives on the coagulation cascade. Hospital Practice, v. 27 , n. 1, p. 97-105, 109-12, 1992. 
ROBERTS, R. M.; MATHIALAGAN, N; DUfFY, J. Y.; SMITH, G. W. Regulation and regulatory role of proteinase inhibitors. Critical Reviews in Eukaryotic Gene Expression, v. 5, n. 3-4, p. 385-436, 1995.

Robinson, A. J.; Kropatkin, M.; AgGeler, P. M. Hageman factor (factor XII) deficiency in marine mammals. Science, v. 166, n. 911, p. 1420-2, 1969.

Rosenberg, J. S.; MCKenNA, P. W.; RosenberG, R. D. Inhibition of human factor IXa by human antithrombin. The Journal of Biological Chemistry, v. 250, n. 23, p. 8883-8, 1975.

ROSENBERG, R. D. Biochemistry of heparin antithrombin interactions, and the physiologic role of this natural anticoagulant mechanism. The American Journal of Medicine, v. 87, n. 3B, p. 2S-9S, 1989.

RosenberG, R. D.; Damus, P. S. The purification and mechanism of action of human antithrombin-heparin cofactor. The Journal of Biological Chemistry, v. 248, n. 18, p. 6490-505, 1973.

Rosenberg, R. D. The heparin-antithrombin system: a natural anticoagulant mechanism. In: Colman, W. H., J.; Marder, V. J.; Salzman, E. W. (Ed.). Hemostasis and thrombosis: basic principles and clinical practice. Philadelphia: Lippincott, p. 837860, 1994. 
ROSENFELD, S.; GLASS, S. The inhibiting effect of snake bloods upon the hemorrhagic action of viper venoms on mice. The American Journal of the Medical Sciences, v. 199, p. 482$6,1940$.

Saito, H.; Poon, M.; Goldsmith, G. H.; Ratnoff, O. D.; Arnason, U. Studies on the blood clotting and fibrinolytic system in the plasma from a sei (baleen) whale. Proceedings of the Society of Experimental Biology and Medicine, v. 152, n. 4, p. 503-7, 1976.

SAlte, R.; NorberG, K.; OdegaARd, O. R. Some functional properties of teleost antithrombin. Thrombosis Research, v. 80, n. 3, p. 193-200, 1995.

SAlveSEn, G. E. P. Proteinase inhibitor: alpha2-macroglobulins, serpins and kinins. In: Colman, R. W.; HirSh, J.; Marder, V. J.; SAlZman, E. W. (Ed.). Hemostasis and Thrombosis: Basic Principles and Clinical Practice. Philadelphia: Lippincott, p. 241-258, 1994.

SAZIMA, I. Um estudo comportamental da jararaca, Bothrops jararaca, com uso de marcas naturais. Memórias do Instituto Butantan, v. 50, p. 83-99, 1988.

SAZIMA, I. Natural history of the jararaca pitvipers, Bothrops jararaca. In: Campbell, J. A., Brodiejr, E. D. (Ed.). Biology of the pitvipers. Tyler: Selva, p. 199-216, 1992.

Silverman, G. A.; Bird, P. I.; Carrell, R. W.; Church, F. C.; Coughlin, P. B.; Gettins, P. G.; Irving, J. A.; Lomas, D. A.; Luke, C. J.; Moyer, R. W.; Pemberton, P. A.; RemoldO'donnell, E.; Salvesen, G. S.; Travis, J.; Whisstock, J. C. The serpins are an 
expanding superfamily of structurally similar but functionally diverse proteins. Evolution, mechanism of inhibition, novel functions, and a revised nomenclature. The Journal of Biological Chemistry, v. 276, n. 36, p. 33293-6, 2001.

Smith, P. K.; Krohn, R. I.; Hermanson, G. T.; Mallia, A. K.; Gartner, F. H.; Provenzano, M. D.; Fujimoto, E. K.; Goeke, N. M.; Olson, B. J.; KlenK, D. C. Measurement of protein using bicinchoninic acid. Analytical Biochemistry, v. 150, n. 1, p. 76-85, 1985.

SteIn, P. E.; CARRELL, R. W. What do dysfunctional serpins tell us about molecular mobility and disease? Nature Structural Biology, v. 2, n. 2, p. 96-113, 1995.

Stoscheck, C. M. Quantification of protein. Methods in Enzymology, v. 182, p. 50-68, 1990.

Stubbs, M. T.; Bode, W. Coagulation factors and their inhibitors. Current Opinion in Structural Biology, v. 4, n. 6, p. 823-32, 1994.

Summaria, L.; Boreisha, I. G.; ArZadon, L.; Robbins, K. C. Activation of human Gluplasminogen to Glu-plasmin by urokinase in presence of plasmin inhibitors. Streptomyces leupeptin and human plasma alpha1-antitrypsin and antithrombin III (plus heparin). The Journal of Biological Chemistry, v. 252, n. 11, p. 3945-51, 1977.

Tanaka-Azevedo, A. M.; Tanaka, A. S.; Sano-Martins, I. S. A new blood coagulation inhibitor from the snake Bothrops jararaca plasma: isolation and characterization. 
Biochemical and Biophysical Research Communications, v. 308, n. 4, p. 706-12, 2003.

Tanaka-Azevedo, A. M.; Torquato, R. J.; Tanaka, A. S.; Sano-Martins, I. S. Characterization of Bothrops jararaca coagulation inhibitor (BjI) and presence of similar protein in plasma of other animals. Toxicon, v. 44, n. 3, p. 289-94, 2004.

Tanizaki, M. M.; Kawasaki, H.; SuzUKi, K.; Mandelbaum, F. R. Purification of a proteinase inhibitor from the plasma of Bothrops jararaca (jararaca). Toxicon, v. 29, n. 6, p. 67381, 1991.

TAPPER, H.; HERWALD, H. Modulation of hemostatic mechanisms in bacterial infectious diseases. Blood, v. 96, n. 7, p. 2329-37, 2000.

THALER, E.; SCHMER, G. A simple two-step isolation procedure for human and bovine antithrombin II/III (heparin cofactor): a comparison of two methods. British Journal of Haematology, v. 31, n. 2, p. 233-43, 1975.

Theopold, U.; Li, D.; Fabbri, M.; Scherfer, C.; Schmidt, O. The coagulation of insect hemolymph. Cellular and Molecular Life Sciences, v. 59, n. 2, p. 363-72, 2002.

Toole, J. J.; Pittman, D. D; OrR, E. C.; Murtha, P.; Wasley, L. C.; Kaufman, R. J. A large region (approximately equal to $95 \mathrm{kDa}$ ) of human factor VIII is dispensable for in vitro 
procoagulant activity. Proceedings of the National Academy of Sciences of the United States, v. 83, n. 16, p. 5939-42, 1986.

Travis, J.; Salvesen, G. S. Human plasma proteinase inhibitors. Annual Review of Biochemistry, v. 52, p. 655-709, 1983.

Triplett, D. A. Coagulation and bleeding disorders: review and update. Clinical Chemistry, v. 46, n. 8, p. 1260-9, 2000.

TwINING, S. S. Regulation of proteolytic activity in tissues. Critical Reviews in Biochemistry and Molecular Biology, v. 29, n. 5, p. 315-83, 1994.

Underwood, G. A. A contribution to the classification of snakes. London: Trustees of the Britsh Museum Natural (Natural History), 179 p., 1967.

ZwaAl, R. F.; COMfurius, P.; Bevers, E. M. Lipid-protein interactions in blood coagulation. Biochimica et Biophysica Acta, v. 1376, n. 3, p. 433-53, 1998. 


\section{Biografia}

\section{Formação Acadêmica/Titulação}

2003 - 2006 Graduação em Biologia pela Universidade Presbiteriana Mackenzie, São Paulo, Brasil.

Título do trabalho de conclusão de curso: Estudo da presença do inibidor da atividade coagulante da trombina (BjI) do plasma da serpente Bothrops jararaca em plasmas de outras serpentes e isolamento deste inibidor a partir do sangue da serpente Crotalus durissus terrificus.

Orientadora: Anita Mitico Tanaka Azevedo.

Bolsista da Fundação de Amparo à Pesquisa do Estado de São Paulo (FAPESP).

2004 - 2005 Licenciatura Plena pela Universidade Presbiteriana Mackenzie, São Paulo, Brasil.

\section{Produção bibliográfica}

\section{Artigos completos publicados em periódicos}

1. Morais, KB, Grego, K F e Tanaka-Azevedo, AM.

Identification of proteins similar to Bothrops jararaca coagulation inhibitor (BjI) in the plasmas of Bothrops alternatus, Bothrops jararacussu and Crotalus durissus terrificus snakes. 
Comparative Biochemistry and Physiology, Part B (Biochemistry \& Molecular Biology), v.149, p.236-240, 2008.

Palavras-chave: blood coagulation, snake plasma, Bothrops jararaca, thrombin inhibitor, Viperidae.

Áreas do conhecimento: Fisiologia Comparada.

2. Vieira, CO, Tanaka, AS, Sano-Martins, IS, Morais, KB, Santoro, ML, Tanaka-Azevedo, AM.

Bothrops jararaca fibrinogen and its resistance to hydrolysis evoked by snake venoms. Comparative Biochemistry and Physiology, Part B (Biochemistry \& Molecular Biology), v.151, p.428-432, 2008.

Palavras-chave: Bothrops jararaca, blood coagulation, fibrinogen, reptiles, snake plasma. Áreas do conhecimento: Fisiologia Comparada.

3. Morais, KB, Vieira, CO, Hirata IY e Tanaka-Azevedo, AM.

Bothrops jararaca antithrombin: isolation, characterization and comparison with other animal antithrombins. Comparative Biochemistry and Physiology, Part B (Biochemistry \& Molecular Biology), v.152, p.171-176, 2009.

Palavras-chave: Antithrombin, serpin, amino acid sequence, snake plasma, Bothrops jararaca. Áreas do conhecimento: Fisiologia Comparada. 